\title{
International Nosocomial Infection Control Consortium (INICC) Report, Data Summary of 36 Countries, for 2004- 2009.
}

Victor D. Rosenthal' , Hu Bijie2, Dennis G. Maki3, Yatin Mehta ${ }^{4}$, Anucha Apisarnthanarak', Eduardo A. Medeiros6, Hakan Leblebicioglu7, Dale Fisher ${ }^{8}$, Carlos Álvarez-Moreno", Ilham Abu Khader10, Marisela Del Rocío González Martínez11, Luis E. Cuellar12, Josephine Anne Navoa-Ng13, Rédouane Abouqal14, Humberto Guanche Garcell15, Zan Mitrev16, María Catalina Pirez García17, Asma Hamdi18, Lourdes Dueñas 19, Elsie Cancel20, Vaidotas Gurskis'21, Ossama Rasslan22, Altaf Ahmed23, Souha S Kanj24, Olber Chavarría Ugalde25, Trudell Mapp26, Lul Raka27, Cheong Yuet Meng28, Le Thi Anh Thu29, Sameeh Ghazal30, Achilleas Gikas31, Leonardo Pazmiño Narváez32, Nepomuceno Mejía 33 , Nassya Hadjieva34, May Osman Gamar Elanbya ${ }^{35}$, María Eugenia Guzmán Siritł36, Kushlani Jayatilleke ${ }^{37}$.

1- International Nosocomial Infection Control Consortium, Buenos Aires, Argentina, 2- Zhongshan Hospital, Shanghai, China; 3- University of Wisconsin Medical School, Madison, Wisconsin, USA 4- Medanta the Medcity,

New Delhi, India; 5-Thammasat University Hospital, Pratumthani, Thailand; 6- Hospital São Paulo, São Paulo,

Brazil; 7- Ondokuz Mayis University Medical School, Samsun, Turkey; 8- Singapore University Hospital, Singapore,

Republic of Singapore; 9- Hospital Universitario San Ignacio, Universidad Pontificia Javeriana, Bogotá, Colombia; 10- Jordan University Hospital, Amman; 11 - Instituto Mexicano del Seguro Social, Torreón, Mexico; 12Instituto Nacional de Enfermedades Neoplásicas (INEN), Lima, Peru; 13- St. Luke's Medical Center, Quezon City,

Philippines; 14- Ibn Sina-Medical ICU, Rabat, Morocco; 15- Hospital Docente Clínico Quirúrgico "Joaquín Albarrán Domínguez", La Habana, Cuba; 16- Filip II Special Hospital for Surgery, Skopje, Macedonia; 17- Centro Hospitalario Pereira Rosell Bouar, Montevideo, Uruguay; 18- Hôpital d'Enfants, Tunis, Tunisia; 19- Hospital Nacional de Niños Benjamin Bloom, San Salvador, El Salvador; 20- San Jorge Children's Hospital- Asociación Epidemiólogos de Puerto Rico, Guaynabo; 21- Hospital of Kaunas University of Medicine, Kaunas, Lithuania; 22Ain Shams Faculty of Medicine, Cairo, Egypt; 23- Liaquat National Hospital, Karachi, Pakistan; 24- American University of Beirut Medical Center, Beirut, Lebanon; 25- Hospital Hotel La Católica, San José, Costa Rica; 26-

Clínica Hospital San Fernando, Panama City, Panama; 27- National Institute for Public Health of Kosova and Medical School, Prishtina University; 28- Sunway Medical Centre Berhad and Monash University Sunway Campus, Petaling Jaya, Malaysia; 29- Cho Ray Hospital, Ho Chi Minh City, Vietnam; 30- King Fahad Medical City, Riyadh, Saudi Arabia; 31 - University Hospital of Heraklion, Heraklion, Greece; 32- Hospital Eugenio Espejo, Quito, Ecuador; 33- Hospital General de la Plaza de la Salud, Santo Domingo, Dominican Republic; 34- Queen Joana, Sofia, Bulgaria; 35- Bahry Accident \& Emergency Hospital, Khartoum, Sudan; 36- Hospital Militar Dr. Carlos Arvelo, Caracas, Venezuela; 37- Sri Jayewardenepura General Hospital, Nugegoda, Sri Lanka.

*For a list of members of the International Nosocomial Infection Control Consortium, see the Appendix.

Reprint requests:

Victor D. Rosenthal, MD. MSc. CIC.

Address: International Nosocomial Infection Control Consortium (INICC), Corrientes Ave \# 4580, Floor 12, Apt D, Buenos Aires, ZIP 1195, Argentina.

Email: victor_rosenthal@inicc.org 


\section{Author Contributions:}

a. Idea, conception and design: Victor D. Rosenthal.

b. Software development: Victor D. Rosenthal.

c. Assembly of data: Victor D. Rosenthal.

d. Analysis and interpretation of the data: Victor D. Rosenthal.

e. Epidemiological analysis: Victor D. Rosenthal.

f. Statistical analysis: Victor D. Rosenthal.

g. Administrative, technical, and logistic support: Victor D. Rosenthal,

h. Drafting of the article: Victor D. Rosenthal and Dennis G Maki.

i. Critical revision of the article for important intellectual content: All byline authors.

j. Final approval of the article: All byline authors.

k. Provision of study patients: All byline authors, except Dennis G Maki.

I. Collection of data: All byline authors, except Dennis $G$ Maki.

m. Funding: Victor D. Rosenthal and Foundation to Fight against Nosocomial Infections funds all the activities at INICC head quarters. 


\section{*International Infection Control Consortium, listed by country alphabetically}

Argentina: María Laura Frías, Griselda Churruarín (Clínica Modelo de Lanús, Lanús); Daniel Sztokhamer (Clínica Estrada, Buenos Aires); Luis Pedro Flynn, Diego Rausch, Alejandro Spagnolo (Sanatorio Británico, Rosario); Beatriz Santero, Luisa C. Soroka (Hospital Interzonal General de Agudos Evita, Lanús); Silvia Forciniti, Marta Blasco, Carmen B. Lezcano (Hospital Interzonal General de Agudos Pedro Fiorito, Avellaneda); Carlos Esteban Lastra (Hospital Narciso López, Lanús); Miguel Ángel Fernández Bedoya, Adrián Costamagna, Gustavo Ruiz Dheza, Jorge Ávalos, Marcelo Álvarez (Centro Médico Bernal, Buenos Aires); Guillermo Benchetrit, Claudio Bonaventura, Maria de los Ángeles Caridi, Adriana Messina, Beatriz Ricci (Centro Gallego de Buenos Aires, Buenos Aires); Mónica Viegas, Beatriz Marta Alicia Di Núbila, Diana Lanzetta, Leonardo J. Fernández, María Adelaida Rossetti, Adriana Romani, Claudia Migazzi, Clarisa Barolin, Estela Martínez (Hospital Interzonal General de Agudos Presidente Perón, Avellaneda); Marisa Liliana Bernan, María Rosa Bay, Flavia Ruiz Diaz (HGZA San Roque de Gonnet, La Plata); Claudia Beatriz Dominguez, Gloria Ester Coria, María Elena Martinelli (Obra Social de Empleados Públicos- Sanatorio Fleming, Mendoza).

Brazil: Gorki Grinberg, Iselde Buchner Ferreira, Raquel Baver Cechinel (Hospital General Porto Alegre, Porto Alegre); Bruna Boaria Zanandrea, Carolina Rohnkohl, Marcos Regalin: (Hospital Sao Miguel, Joaçaba / SC); Jamile Leda Spessatto, Ricardo Scopel Pasini, Shaline Ferla (Hospital Universitario Santa Teresina, Joaçaba / SC); (Maternidade e Hospital Día Santa Luíza, Balneario Camboriú); Reinaldo Salomao, Maria Ângela Maretti da Silva, Clélia Heloísa de Jesus Silva, Margarete Vilins, Sergio Blecher (Hospital Santa Marcelina, São Paulo); Daniela Bicudo Angelieri (Hospital São Paulo, São Paulo); Ricardo de Souza Kuchenbecker, Márcia Rosane Pires, Rodrigo Pires dos Santos, Nádia Mora Kuplich (Hospital de Clínicas de Porto Alegre, Porto Alegre); Erci Maria Onzi Siliprandi, Rodrigo Pires dos Santos (Instituto de Cardiologia do Rio Grande do Sul, Porto Alegre); Raquel Baver Cechinel, Angélica Peres Do-Amaral (Complexo Hospitalar Santa Casa de Porto Alegre, Porto Alegre); Cristiane Pavanello Rodrigues Silva, María Lucia Neves Biancalana (Hospital Samaritano, São Paulo); Tarquino Erástides G. Sánchez, Roberto Valente, Daniele Apolinário (Hospital Anchieta LTDA, Taguatinga); Luiz Fernando Baqueiro Freitas, Maria Cecilia Imori dos Santos (Hospital Santa Lydia, Ribeirao Preto); Julia Marcia Maluf Lopes, Paula Cristina Pinto Valadares, Joana Paula Batista, María Aparecida dos Santos Campos (Hospital Infantil João Paulo II- FHEMIG, Belo Horizonte); María Luiza Moretti, Luiz Gustavo Cardoso, Alinio Trabaos (Hospital de Clínicas FCM- UNICAMP, Campinas); lanick Souto Martins, Patricia Tavares Dos Santos, Debora Otero Brjtto Passos Pinhejro, Juliana Silva De Abreu, (Hospital do Câncer/ Instituto Nacional do Câncer, Río de Janeiro); Rosana Richtmann, Tatiana Rodríguez, Sandra Regina Baltieri (Hospital Maternidade Santa Joana, São Paulo); Marina Moreira, Gabriela Fagundes Stadtlober, Adriana Giunta Cavaglieri (Hospital Universitario de Taubate, Taubaté).

Bulgaria: D. Karadimovm, V. Velinova (Queen Joana, Sofia)

China: Jin Ai Qin, Huang Juan, Huang Chun Fang (The First Affiliated Hospital of Guangxi Medical University, Nanning); Xiandong Gao, Tao Lili (Zhongshan Hospital, Shanghai); Suo Yao, Wang Hungmei (The Second Affiliated Hospital of Xi'an Jiaotong University, Medical College, Xi'an); Cao Bin, Li Ruisheng (Chaoyang Hospital, Beijing); Yun Yang (The First Affiliated Hospital Shanxi Medical University, Tai Yuan); Yeguxiang (Yangpu Hospital, Shanghai); XU Ziqin, Wu Hong Mei, Gao Sheng Chun (The Third people's Hospital of Wenzhou, Wenzhou); Xuesong Yang (Peking University Third Hospital, Beijing); Aiguo Gan (Zhongshan Hospital Cancer Center, Shanghai); Aiguo Zhang, Jiangmeng Luo (Songjian Hospital Affiliated To Shanghai Jiaotong University School Of Medicine, Shanghai); Aihua Zhao, Fenghong Li (Zhabei District Central Hospital, Shanghai); Baozheng Liu, Meiying Gao (Jinshan Central Hospital, Shanghai); Bo Zhao, Ling Wei (Huashan Hospital Baoshan Fudan University, Shanghai); Chuanqing Wang, Lanzhi Fang (Children's Hospital Of Fudan University, Shanghai); Chuntao Yi, Xiaoling Xie (Shanghai 8th People's Hospital, Shanghai); Fang Ling, Yuxin Wu (Zhongshan Hospital Qingpu Branch, Shanghai); Fangrui Xu, Fang Feng (Minhang District Central Hospital, Shanghai); Fangyi Weng, Guihong Dong (Longhua Hospital, Shanghai); Guxiang Ye, Wenwei Yang (Yangpu District Central Hospital, Shanghai); Hong Yu, Huiying Yang (Shanghai Tenth People's Hospital, Shanghai); Huafang Yan, Aihua Mao (Nanhui District Central Hospital, Shanghai); Huamin Zhou, Wei Chen (Baogang Hospital Attached No.2 Shanghai Medical University, Shanghai); Huang Gong (Shanghai Post \& Tele Hospital, Shanghai); Huifang Tan, Yanping Liu (Shanghai Gongli Hospital, Shanghai); Huiping Wu, Dongping Tang (Changning Center Hospital, Shanghai); Jianguo Hao, Hongyu Zhang (Shanghai Seventh People's Hoapital, Shanghai); Jianguo Wang, Youdi Qiu (Jinshan Hospital, Fudan University, Shanghai); Jianhua Yu, Xiaohong Gu (Shanghai Municipal Hospital Of 
Traditional Chinese Medicine, Shanghai); Jianxin Jiang, Min Zhang (Shanghai East Hospital, Tongji University, Shanghai); Jin Miu, Wenqi Zhao (Huangpu District Central Hospital, Shanghai); Junfeng Shi, Lei Li (Xinhua Hospital Of Shanghai Second Medical University, Shanghai); Kewei Duo, Lixia Cai (Fudan University Shanghai Cancer Center, Shanghai); Lei Liu (Shanghai Peoples Armed Police Corps Hospital, Shanghai); Li Li, Lei Hua (Shanghai No.6 People's Hospital, Shanghai); Qihui Shao, Yi An (Tongji Hospital Of Tongji University, Shanghai); Qing Lu, Guanghui Li (Shanghai Huashan Hospital, Shanghai); Ruizheng Sun, Haichun Yu (Pla No.411 Hospital, Shanghai); Weiming Zhang, Zhenmei Tao (Jiading District Central Hospital Of Shanghai, Shanghai); Weixiu Wang, Yimian Shen (Putuo District Center Hospital, Shanghai); Wenji Fan, Haiwei Chen (Shanghai First People's Hospital, Shanghai); Xiaoping Yao, Hui Wen (Jian'an District Center Hospital Of Shanghai, Shanghai); Xudong Xiong, Hongmei XU (Shuguan Hospital, Shanghai); Xueqing Liu, Mingmin Huang (Shanghai St. Luck's Hospital, Shanghai); Xuewen Wang, Guangnan Shao (Yueyan Hospital Of Intergrated Traditional Chinese And Western Medicine, Shanghai); Yanling Yuan, Yan Cao (Shanghai People's Hospital Baoshan Branch, Shanghai); Yanyin Chen, Xiaomei Chen (Shanghai Xuhui Central Hospital, Shanghai); Yaping Gu, Laifeng Zhu (Renji Hospital Chongming Branch, Shanghai); Yaping Huang, Meijuan Wang (Shanghai 2nd People's Hospital, Shanghai); Yaping Wang, Ying Shen (The Fifth People's Hospital Of Shanghai,Fudan University, Shanghai); Yindi Wu, Yanhua Mao (Shanghai Pulmonary Hospital, Shanghai); Yinling Cheng, Chunjiang Zhao (Changhai Hospital Of Shanghai, Shanghai); Yongli Sun, Biqing Zhu (Yangpu East Hospital, Shanghai); Yulan Sun, Mingzheng Cai (Hospital Of The Second Military Medical University, Shanghai); Yun Zhang, Min Xue (Shanghai Jiangong Hospital, Shanghai); Yunfang Zhou, Ruhui Zhang (Shanghai Children's Medical Center, Shanghai); Yuping Du, Dongmei Li (Shanghai Tcm-Integrated Hospital, Shanghai); Yuxing Ni, Lijun Zhang (Rui Jin Hospital, Shanghai Jiao Tong University School Of Medicine, Shanghai); Zhiqiong Zhong, Guoming Zhu (Putuo District People's Hospital, Shanghai); Zhizhen Yu, Minhua Cao (Huadong Hospital Affiliated To Fudan University, Shanghai); Zhongxian Song, Jiali XU (The 455th Hospital Of People's Liberation Army, Shanghai); Zimei Tong, Peihua GU (International Peace Maternity And Children's Hospital Of The China Welfare Institute, Shanghai);

Colombia: Julio Garzón Agudelo (Hospital Videlmédica, Bogotá); Otto Sussmann, Beatriz Eugenia Mojica (Clínica Nueva, Bogotá); Catherine Rojas, Humberto Beltran, Jerson Paez (Centro Policlínico del Olaya, Bogotá); Wilmer Villamil Gómez, Luis Dajud, Mariela Mendoza, Patrick Arrieta (Clínica de la Sabana, Sucre); Laline Osorio (Hospital Simón Bolivar ESE, Bogotá); Narda Olarte, Alberto Valderrama (Hospital El Tunal ESE, Bogotá); Heidi Johanna Muñoz (Clínica Reina Sofía, Bogotá); Nayide Barahona Guzmán, Marena Rodríguez Ferrer, Guillermo Sarmiento Villa, Alfredo Lagares Guzmán (Universidad Simón Bolivar, Barranquilla); Claudia Linares (Hospital Universitario San Ignacio, Universidad Pontificia Javeriana, Bogotá); Lorena Matta Cortés, Luis Fernando Rendon Campo (Corporación Comfenalco Valle-Universidad Libre, Santiago de Cali); Wilmer Villamil Gómez, Antonio Menco, Patrick Arrieta (Clínica Santa María, Sucre); María Eugenia Rodríguez Calderón (Hospital La Victoria, Bogotá); Dr. Edwin Chapeta Parada (Hospital San Vicente de Arauca, Arauca); Ana María Pérez Fernandez, Ivan Francisco Pinilla Martínez, Paula Andrea Martínez Saleg (Clínica Central Del Quindio, Armenia); Yazmín León Vega, Elkin Lemos Luengas, Carolina Romero Ramos (Clínica del Occidente, Bogotá); Herlidia Taboada Hernández (Hospital de San José, Bogotá); David Yepes Gomez, Bernarda Maria Vergara Gomez, Marcel Gaviria Ruiz (Clínica CES, Medellín); Juan Carlos Torres Millán, Moisés Ulises Torres López (UCl Valle de San Nicolás, Antioquia). Edwin Chapeta Parada, Andrés Eduardo Mindiola Rochel (Hospital San Vicente de Arauca, Aurauca).

Costa Rica: Rosalía Fernández Hidalgo, Juan Manuel Aragón Calzada, Gabriel Muñoz, Adela Ruiz Argüello (Hospital Clínica Bíblica, San José); (Hospital Hotel La Católica, San José).

Cuba: Clara Morales Pérez (Hospital Docente Clínico Quirúrgico "Joaquín Albarrán Domínguez", La Habana); Osiel Requejo Pino, Orlando Delgado González, Dania Fernández González (Hospital Universitario Gral. Calixto García, La Habana).

Dominican Republic: Carolina Martínez Rodríguez de Wang, Ramona Severino, Gilda Tolari (Santo Domingo, Dominican Republic).

Ecuador: Jorge Washington Vélez, Mario Alejandro Cadena Zapata, Marcia Jacqueline Valle, Silvia Guayasamín (Hospital Eugenio Espejo, Quito). 
Egypt: Zeinab Salah Seliem, El Kholy Amani Ali, Doaa Abdel-Aziz (Abo El Reesh, Cairo); Muhamed Abd El Sabour, Mahmoud Kalil, Adel Saeed, Maha El Gafarey, Lamia Fouad, Tamer Muhamed, Hedya Saeed (Ain Shams Faculty of Medicine, Cairo).

El Salvador: Ana Concepción Bran de Casares, Lilian de Jesús Machuca (Hospital Nacional de Niños Benjamin Bloom, San Salvador).

Greece: Kalliopi Chaniotaki, Constantinos Tsioutis, Dimitris Bampalis (University Hospital of Heraklion, Heraklion).

India: Ramachadran Gopinath, Nallagonda Ravindra (Nizam's Institute of Medical Sciences, Hyderabad); Anil Karlekar (Escorts Heart Institute \& Research Centre, New Delhi); Sanjeev Sood, Neeru Verma (Military Hospital, Jodhpur); Nagamani Sen, Kandasamy Subramani, John Prakash Raj (Christian Medical College, Vellore); Purva Mathur, Subodh Kumar (JPNA Trauma Centre- All India Institute of Medical Sciences, New Delhi); Samir Sahu (Kalinga Hospital, Bhubaneswar); Deepak Govil, Namita Jaggi, Shaleen Bhatnagar (Artemis Health Institute, New Delhi); Sheila Nainan Myatra, Divatia, Rohini Kelkar, Sanjay Biswas, Sandhya Raut, Sulochana Sampat, Rishi Kumar (Tata Memorial Hospital, Mumbai); Subhash Kumar Todi, Arpita Bhakta, Mahuya Bhattacharjee (AMRI Hospitals, Kolkata); Dr. Bala Ramachandran (KK Childs Trust Hospital, Chennai); Murali Chakravarthy, B.N.Gokul, Sukanya R., Leema Pushparaj (Wockhardt Hospitals, Bangalore); Sanjeev Singh, Kavitha Radhakrishnan (Amrita Institute of Medical Sciences \& Research Center, Kochi); F. E. Udwadia, Reshma Ansari, Aruna Poojary, Geeta Koppikar, Lata Bhandarkar, Shital Jadhav (Breach Candy Hospital Trust, Mumbai); Arpita Dwivedy, Suvin Shetty, Sheena Binu (Dr L H Hiranandani Hospital, Mumbai); Mandakini Pawar, Amit Gupta, Narinder Saini (Pushpanjali Crosslay Hospital, Ghaziabad); Vatsal Kothari, Tanu Singhal, Sweta Shah (Kokilaben Dhirubhai Ambani Hospital, Mumbai); Camilla Rodrigues, Ashit Hegd, Farahad Kapadia (PD Hinduja National Hospital \& Medical Research Centre, Mumbai); Preeti Mehta, Pallavi Surase, Vatsal Kothari (Seth GS Med College, Mumbai); Sathyanarayanan Narayanan (Malabar Institute of Medical Sciences LTD., Calicut); Nita Munshi (Ruby Hall Clinic, Pune); Vikram Padbidri, Romini Dawhale, Sheena Mary Jacobs (Jehangir Hospital, Pune).

Jordan: Najwa Khuri-bulos, Azmi Mahafzah (Jordan University Hospital, Amman).

Kosovo: Nehat Baftiu, Gazmend Spahija (National University Clinical Center of Kosovo, Prishtina).

Lebanon: Nada Zahreddine, Lamia Alamuddin, Zeina Kanafani (American University of Beirut Medical Center, Beirut).

Lithuania: Algirdas Dagys, Tomas Kondratas (Hospital of Kaunas University of Medicine, Kaunas). ut). Rimantas Kevalas (Kaunas University of Medicine, Children Clinic, Kaunas).

Macedonia: Tanja Anguseva, Vilma Ampova, Snezana Tufekcievska Guroska (Filip II Special Hospital for Surgery, Skopje).

Malaysia: Jegathesan Manikavasagam, Lian Huat Tan, Kerinjeet Kaur (Sunway Medical Centre Berhad and Monash University Sunway Campus, Petaling Jaya); Ojan Assadian, Roswitha Wolfram, Paramjit Kaur (Prince Court Medical Center, Kuala Lumpur).

Mexico: Martha Sobreyra Oropeza (Hospital de la Mujer, México DF); Alberto Armas Ruiz, Roberto Campuzano, Jorge Mena Brito (Centro Médico La Raza IMSS, México DF); Irma Pérez Serrato, Martha Sánchez López (Hospital General de la Celaya, Celaya); Héctor Torres Hernández, Amalia Chávez Gómez, Jaime Rivera Morales, Julián Enrique Valero Rodríguez (Hospital General de Irapuato, Irapuato); Jorge Horacio Portillo Gallo, Fernando Aguilera Almazán, Gaspar Iglesias Miramontes, Ma. Del Rosario Vázquez Olivas, Alicia Sánchez Chávez, Yolcey Angulo Espinoza (Hospital CIMA Chihuahua, Chihuahua); Lauro Armenta Gallegos, Dr. Joaquín Sánchez González, Alfonso Monjardín Rochín, Marcos José Serrato Félix (Hospital Gral. De Sonora "Dr. Ernesto Ramos Bours", Hermosillo); Rafael Díaz Peña, Ana Bertha Zavala Gómez, Carlos Ariel Espinoza Gutiérrez (Unidad Médica de Alta Especialidad, Hospital de Pediatría, Guadalajara); María Guadalupe Miranda Novales (Hospital de Pediatría CMN Siglo XXI, IMSS, México D.F); María De Jesús Herver (Hospital General La Villa, México D.F.); Jacobo Ayala Gaytan (Hospital San José-Tec de Monterrey, Monterrey); Jesús A. Galindo Olmeda (Instituto Mexicano del Seguro Social, Torreón); Martha Yolanda Martínez-Marroquín, Andrés 
Hernández, Enrique Ortíz García, Rafael Venegas Cervantes (Centro Médico "Lic. Adolfo López Mateos", Toluca); Gabriel Arteaga-Troncoso, Fernando M. Guerra Infante, Iyari Morales Méndez (Instituto Nacional de Perinatología, Mexico City), Martha Cecilia Culebro Burguete (Hospital de Especialidades Pediátricas, Chiapas);

Morocco: Amina Barkat, Naima Lamdouar Bouazzaoui, Kabiri Meryem (Children Hôspital of Rabat, Rabat); Naoufel Madani, Amine Ali Zeggwagh, Khalid Abidi, Tarek Dendane (Ibn Sina- Medical ICU, Rabat).

Pakistan: Safdar Ghayur Khan, Farheen Ali (Liaquat National Hospital, Karachi); Yasser Hussain, Farhana Butt, Ajaz Fakir (Shaukat Khanum Cancer Hospital and Research Centre, Lahore); Syed Faisal Mahmood, Bushra Jamil, Farheen Ali (Aga Khan University Medical Collage, Karachi); Badaruddin A. Memon, Gul Hassan Bhutto (Public Sector Hospital Khairpur, Khairpur).

Panama: Fernando G. Alfaro, Cecilia Alvarado, Luz Marina De León, Rodolfo Navarro, José Luis Moreno, Rigoberto Cerrad (Clínica Hospital San Fernando, Panama City).

Peru: Alex Castañeda Sabogal, lliana Paredes Goicochea, Abel Arroyo Sanchez, Guillermo Rios Alva, Jorge García Ventura, Miguel Ramírez Aguilar, Niler Segura Plasencia, Teófilo Rodríguez (Hospital Victor Lazarte Echegaray, Trujillo); Eduardo Fernández Maldonado, Manuel Jesús Mayorga Espichan, Liliana Echenique (Clínica San Pablo, Lima); Rosa Rosales, Luis Isidro Castillo Bravo, María Linares Cáceres (Instituto Nacional de Enfermedades Neoplásicas (INEN), Lima); Teodora Atencio Espinoza, Favio Sarmiento López (Hospital Regional de Pucallpa, Pucallpa); María Edelmira Cruz Saldarriaga, Eloy U. Villena Morvelí, Herly Barriga, Milena Sánchez Villacorta, Sandro Castillo Barrios (Hospital Nacional Adolfo Guevara Velasco, Cusco); Socorro Liliana Torres Zegarra, Nazario Silva Astete, Francisco Campos Guevara, Carlos Bazan Mendoza., Augusto Valencia Ramírez, Javier Soto Pastrana (Hospital San Bartolomé, Lima); Fernando Martín Ramírez Wong, Carmen Saman Ángeles, Zoila Díaz Tavera (Hospital María Auxiliadora, Lima); Eliza Ramirez (ESSALUD- Red Asistencial ANCASH- Hospital III, Chimbote); Carlos Enrique La Hoz Vergara, Liliana Mendoza, Gladys Bonzano Sosa (ESSALUD, Huancayo); Celene Manga Chávez (Hospital Nacional Cayetano Heredia de Lima, Lima); Socorro Liliana Torres Zegarra, Nazario Silva Astete, Dr. Francisco Campos Guevara, Dr. Carlos Bazan Mendoza, Augusto Valencia Ramírez, Dr. Javier Soto Pastrana (Hospital Nacional Docente Madre Niño San Bartolomé, Lima).

Philippines: Regina Berba, Glenn Angelo S. Genuino, Rafael J. Consunji, Jacinto Blas V. Mantaring III (Philippine General Hospital, Manila); Victoria D Villanueva, María Corazon V. Tolentino (St. Luke's Medical Center, Quezon City); Yolanda Arreza Galapia (Infection Control Team of National Kidney \& Transplant Institute, Quezon City).

Singapore: Paul Anantharajah Tambyah (Singapore University Hospital, Singapore)

Saudi Arabia: Ahmed Hakawi (King Fahad Medical City, Riyadh).

Sri Lanka: Nishanthi Nawamalika Kaluarachchi, Geethani Anuruddika Samaraweera (Sri Jayewardenepura General Hospital, Nugegoda).

Sudan: Ibrahim M. Sid Ahmed Ali, Asim A.Satti (Bahry Accident \& Emergency Hospital, Khartoum).

Thailand: Silom Jamulitrat (Songklanagarind Hospital, Songkla); Visanu Thamlikitkul (Siriraj Hospital, Mahidol University, Bangkok);

Tunisia: Khaldi Ammar, Asma Hamdi (Hôpital d'Enfants, Tunis).

Turkey: Recep Öztürk, Yalim Dikmen, Gökhan Aygún (Istanbul University Cerrahpasa Medical School, Istanbul); Sercan Ulusoy, Bilgin Arda, Feza Bacakoglu (Ege University Medical Faculty, Izmir); Yesim Cetinkaya Sardan, Gonul Yildirim, Arzu Topeli (Hacettepe University School of Medicine, Ankara); Özay Arıkan Akan, Melek Tulunay, Mehmet Oral, Necmettin Ünal (Ankara University School of Medicine Ibni-Sina Hospital, Ankara); Emine Alp, Bilgehan Aygen (Erciyes University, Faculty of Medicine, Kayseri); Fatma Sirmatel, Mustafa Cengiz, Leyla Yilmaz (Harran University, Faculty of Medicine, Sanliurfa); Asu Özgültekin, Güldem Turan, Nur Akgün (Haydarpasa Hospital, Istanbul); Davut Ozdemir, Ertugrul Guclu, Selvi Erdogan (Duzce Medical School, Duzce); Nurettin Erben, 
Ilhan Ozgunes, Gaye Usluer (Eskisehir Osmangazi University, Eskisehir); Canan Aygun, Sukru Küçüködük (Ondokuz Mayis University Medical School (Neo), Samsun); Dilek Arman, Kenan Hizel (Gazi University Medical School, Ankara); Cengiz Uzun (German Hospital, Istanbul); Huseyin Turgut, Suzan Sacar, Hülya Sungurtekin, Doğaç Uğurcan (Pamukkale University, Denizli); Iftíhar Koksal, Gürdal Yýlmaz, Selçuk Kaya, Hülya Ulusoy (Karadeniz Technical University School of Medicine, Trabzon); Gulden Ersoz, Ali Kaya, Necdet Kuyucu (Mersin University, Faculty of Medicine, Mersin); Saban Esen, Fatma Ulger, Ahmet Dilek (Ondokuz Mayis University Medical School, Samsun); A. Nevzat Yalcin, Ozge Turhan, Sevim Keskin, Eylul Gumus, Oguz Dursun (Akdeniz University, Antalya); Tanil Kendirli, Erdal Ince, Ergin Cliftci, Halil Özdemir (Ankara University School of Medicine, Ankara); A. Pekcan Demiroz, M. Arzu Yetkin, Cemal Bulut, F. Sebnem Erdinc, Cigdem Ataman Hatipoglu (Ankara Training and Research Hospital, Ankara); F. Sebnem Erdinc (Health Ministry Ankara Training and Research Hospital, Ankara); Ayse Erbay (Turkiye Yuksek Ihtisas Education and Research Hospital, Ankara); Ayse Willke, Meliha Meric, Emel Azak (Kocaeli University Faculty of Medicine, Kocaeli); Oral Oncul, Tuncer Haznedaroglu, Levent Gorenek, Ali Acar (Gulhane Military Medical Academy, Haydarpasa Training Hospital, Istanbul).

Uruguay: Eduardo Silvera, Silvia Techera, Adrián Frachia, Gabriela Algorta (Centro Hospitalario Pereira Rosell Bouar, Montevideo).

Venezuela: Zenaida Durán Gil de Añez, Luis Montes Bravo, Nelva Orozco, Eugenia Mejías (Hospital Militar Dr. Carlos Arvelo, Caracas).

Vietnam: Dang Thi Van Trang, Thai Thi Kim Nga, Pham Hông Zruong (Cho Ray Hospital, Ho Chi Minh City). 
Acknowledgments: The authors thank the many health care professionals at each member hospital who assisted with the conduct of surveillance in their hospital, including the surveillance nurses, clinical microbiology laboratory personnel, and the physicians and nurses providing care for the patients during the study; without their cooperation and generous assistance this INICC would not be possible; Mariano Vilar, Debora Lopez Burgardt, and Alejo Ponce de Leon, who work at INICC headquarters in Buenos Aires, for their hard work and commitment to achieve INICC goals; the INICC country coordinators (Altaf Ahmed, Carlos A.Álvarez Moreno, Apisarnthanarak Anucha, Luis E. Cuéllar, Bijie Hu, Hakan Leblebicioglu, Eduardo A. Medeiros, Yatin Mehta, Lul Raka, Toshihiro Mitsuda, and Virgilio Bonilla Sanchez); the INICC Advisory Board (Carla J. Alvarado, Gary L. French, Nicholas Graves, William R. Jarvis, Patricia Lynch, Dennis Maki, Russell N. Olmsted, Didier Pittet, Wing Hong Seto and William Rutala), who have so generously supported this unique international infection control network; and specially to Patricia Lynch, who inspired and supported us to follow our dreams despite obstacles. 
INICC Report 2004-2009 -9

\section{ABSTRACT}

The results of a surveillance study conducted by The International Nosocomial Infection Control Consortium (INICC) from January 2004 through December 2009 in 422 ICUs of 36 countries in Latin America, Asia, Africa, and Europe are herein reported. During the period of the 6-year study, using Centers for Disease Control and Prevention (CDC) US National Healthcare Safety Network (NHSN; formerly the National Nosocomial Infection Surveillance system [NNIS]) definitions for device-associated healthcare-associated infection (DA-HAI), we gathered prospective data from 313,008 patients hospitalized in the consortium's hospital ICUs for an aggregate of 2,194,897 ICU bed days. In spite of the fact that the use of devices in the developing countries' ICUs was remarkably similar to that reported in U.S. ICUs in the CDC'S NHSN, rates of device-associated nosocomial infection were significantly higher in the ICUs of the INICC hospitals: the pooled rate of central lineassociated bloodstream infection (CLAB) in the INICC ICUs, 6.8 per 1000 central line days, is almost three-fold higher than the 2.0 per 1000 central line-days reported in comparable U.S. ICUs, and the overall rate of ventilator-associated pneumonia (VAP) was also far higher, 15.8 vs 3.3 per 1000 ventilator-days, as was the rate of catheter-associated urinary tract infection (CAUTI), 6.3 vs. 3.3 per 1000 catheter-days.

Noticeably, the frequencies of resistance of Pseudomonas aeruginosa isolates to imipenem (47.2\% vs $23.0 \%$ respectively), Klebsiella pneumoniae isolates to ceftazidime $(76.3 \%$ vs $27.1 \%$ respectively), Escherichia coli isolates to ceftazidime $(66.7 \%$ vs $8.1 \%$ respectively), Staphylococcus aureus isolates to methicilin $(84.4 \%$ vs $56.8 \%$ respectively), were also higher in the consortium's ICUs; and the crude unadjusted excess mortalities of devicerelated infections ranged from $7.3 \%$ (CAUTI) to $15.2 \%$ (VAP).

Key Words: INICC; International Nosocomial Infection Control Consortium; network; Hospital infection; nosocomial infection; health care-associated infection; device-associated infection; ventilator-associated pneumonia; catheter-associated urinary tract infection; central line-associated bloodstream infections; bloodstream infection; urinary tract infection; antibiotic resistance; developing countries; limited resources countries; low income countries.. 
INICC Report 2004-2009 -10

\section{INTRODUCTION}

The present is an updated report of data on device-associated infections (DA-HAl) within intensive care units (ICUs) collected by hospitals participating in the International Nosocomial Infection Control Consortium (INICC) $)^{1-17}$ between January 2004 and December 2009.

INICC is an international non-profit, open, multi-center, collaborative healthcare-associated infection control program with a surveillance system based on that of the U.S. National Healthcare Safety Network (NHSN, 18-19 formerly the National Nosocomial Infection Surveillance system [NNIS] ${ }^{20}$ ). INICC was founded in Argentina in 1998, being the first multinational research network established to control and reduce DA-HAl through the analysis of data collected on a voluntary basis by a pool of hospitals worldwide. ${ }^{1-17}$ INICC has the following goals: Create a dynamic global network of hospitals in the developing world that conduct surveillance of device-associated healthcare-associated infections (DA-HAls) by means of standardized definitions and established methodologies, promote implementation of evidence-based infection control practices, and perform applied infection control research; provide training and surveillance tools to individual hospitals which can allow them to conduct outcome and process surveillance of DA-HAls, measure their consequences, and assess the impact of infection control practices; improve safety and quality of health care world-wide through implementation of systematized programs to reduce rates of DA-HAl associated mortality, excess lengths of stay, ${ }^{21-24}$ excess costs and bacterial resistance. 
INICC Report 2004-2009 -11

\section{METHODS}

At this time the INICC has focused on surveillance and prevention of DA-HAI in adult and pediatric ICUs and high-risk nurseries.3, 10, 13, 25 Data are collected using standardized CDC NHSN protocols and definitions. 19-20

The methodology of INICC have both outcome surveillance and process surveillance components. The modules of the components may be used singly or simultaneously, but, once selected; they must be used for a minimum of 1 calendar month. $3,10,13,25$

All DA-HAls of the Outcome Surveillance Component are categorized using standard CDC NHSN definitions that include laboratory and clinical criteria. ${ }^{19}$ Both laboratory-confirmed BSIs and clinical sepsis without microbiologic confirmation of BSI are recorded and reported. 26

Data are classified into specific module protocols addressing the following: DA-HAI rates: excess length of stay, evaluation of DA-HAl costs, crude excess mortality, microbiological profile, bacterial resistance, and antimicrobial-use data within the Outcome Surveillance Component. Besides, INICC methodology includes a process for adjudication and validation of reported HAls. $3,10,13,25$

Infection control professionals (ICPs) collect data on central line-associated primary bloodstream infections (CLABs), catheter-associated urinary tract infections (CAUTIS) and ventilator-associated pneumonias (VAPs) occurring in patients hospitalized in a specific patient-care location, in nearly all hospitals. ICUs are stratified according to the patient population: adult, pediatric or neonatal units (NICUs).

All NICUs are level III or level II/III units, and ICPs collect data on CLABs and umbilical catheter-associated primary BSIs or VAPs for each of 5 birth-weight categories (<750 g, 750-1000 g, 1001 - 1500 g, 1501 - 2500 g, >2500 g). Corresponding denominator data, patient-days and specific device-days are also collected.

INICC also received aggregated data from hospitals with previous experience in conducting surveillance of DA HAls. Original and aggregated data was used to calculate DA-HAI rates. In order to calculate mortality, and length of stay, only original data was used. The Process Surveillance Component includes the following modules: hand hygiene compliance monitoring in ICUs; central and peripheral vascular catheter care compliance monitoring; urinary catheter care compliance monitoring; monitoring of compliance with measures to prevent VAP; and performance feedback. Data from the Process Surveillance Module on hand hygiene compliance are included in this report. 3, 10, 13, 25

The identity of all INICC hospitals, cities and countries is confidential, in accordance with the INICC charter. 
INICC Report 2004-2009 -12

\section{RESULTS}

Table 1 shows characteristics of 422 ICUs from 36 countries in Latin America, Asia, Africa, and Europe currently participating in INICC that contributed data for this report. The participation of hospitals on INICC Program is as follows: mean length of participation 23.9, SD 21.7 months, and range 1 to 72 months.

For the Outcome Surveillance Component, DA-HAl rates, device utilization (DU) ratios, crude excess mortality by specific type of DA-HAl, antimicrobial utilization, and bacterial resistance for January 2004 through December 2009 are summarized (Tables 2-17).

Tables 2-7 show DA-HAI rates and DU ratios by infection type (CLAB, CAUTI, and VAP) in adult and pediatric ICUs. The data for adult combined medical/surgical ICUs were not stratified by type or size of hospital. Devicedays consisted of the total number of central line-days, urinary catheter-days, or ventilator days. The DU ratio constitutes an extrinsic risk factor for DA-HAI. ${ }^{19-20}$ DU also comprises a marker for severity of illness of patients, vis-a-vis, patients' susceptibility to DA-HAl.

Tables 8-11 show DA-HAI rates and DU ratios from the High Risk Nursery Component of the INICC system for CLABS and VAPs. For NICUs, device-days consist of the total number of central line-days, umbilical catheter days, and ventilator-days. The data for neonatal ICUs were stratified by weight.

Tables 12 and 13 provide data on crude ICU mortality in patients hospitalized in each type of unit during the surveillance period, with and without DA-HAl, and crude excess mortality of adult and pediatric patients with CLAB, CAUTI, and VAP, and infants in NICUs with CLAB or VAP.

Tables 14 and 15 provide data on crude length of stay of patients hospitalized in each type of unit during the surveillance period with and without DA-HAl and crude excess length of stay of adult and pediatric patients with CLAB, CAUTI, and VAP and infants in NICUs with CLAB or VAP.

Table 16 provides data on bacterial resistance of pathogens isolated from patients with DA-HAl in adult and pediatric ICUs and NICUs.

Table 17 provides data on hand hygiene compliance in each type of unit.

Tables 18 and 19 compare overall rates of CLAB, CAUTI and VAP (Table18) ${ }^{18}$ and rates of antimicrobial resistance (Table 19) ${ }^{27}$ in the INICC and CDC NHSN ICUs.

Table 20 compares rates of CLAB, CAUTI and VAP in the INICC reports published in 2006,32008,10 and 2010.13 
INICC Report 2004-2009 -13

\section{DISCUSSION}

The implementation effectiveness of an integrated infection control program focused on DA-HAl surveillance was demonstrated around 30 years ago, as shown in many studies conducted in the U.S., which results reported that the incidence of DA-HAl can be reduced by as much as 30\%, and that a related reduction in health care costs was feasible as well. ${ }^{28}$ For more than 30 years, the CDC's NNIS/NHSN network has provided benchmarking U.S. ICU data on DA-HAls and antibiotic resistance, which have proven to be invaluable for researchers, and served as an inspiration to the INICC program.3, 10, 13, 25 Initially, INICC's surveillance has concentrated on DA-HAI surveillance in the ICU: a health care setting with the highest DA-HAI rates, in which patients' safety is most seriously threatened, due to their critical condition and exposure to invasive devices. $3,10,13$

The rate of device use in INICC ICUs is analogous or even lower than the one reported of U.S. ICUs by the NNIS/NHSN System;18 however, DA-HAI rates identified in INICC ICUs are exceedingly higher than the published U.S. rates (Table 18). ${ }^{18,29}$ Likewise, the antimicrobial resistance rates found in INICC ICUs for Staphylococcus aureus isolates as resistant to methicillin (MRSA), enterobacteria resistant to ceftazidime (extended-spectrum beta-lactamase producers), and Pseudomonas aeruginosa as resistant to fluoroquinolones were far higher than NHSN ICUs' rates (Table 19). ${ }^{27}$ Nonetheless, the rates found in the INICC ICUs for enterococcal isolates as resistant to vancomycin is much lower than NHSN ICUs' rates. ${ }^{27}$

Such higher DA-HAl rates may reflect the typical ICU situation in limited-resources countries as a whole, ${ }^{30}$ and several reasons have been exposed to explain this fact. ${ }^{30}$ Among the primary plausible causes, it can be mentioned that, in almost all the limited-resources countries, there are still no legally enforceable rules or regulations concerning the implementation of infection control programs, such as national infection control guidelines; yet, in the few cases in which there is a legal framework, adherence to and compliance with the guidelines is most irregular and hospital accreditation is not mandatory. In most INICC hospitals, lack of official regulations is strongly correlated to the considerable variability found in the compliance with hand hygiene recommendations. This situation is further emphasized by the fact that administrative and financial support in most INICC hospitals is insufficient to fund infection control programs, ${ }^{30}$ and invariably results in extremely low nurse-to-patient staffing ratios-which have proved to be highly connected to high DA-HAI rates in ICUs-, 3 
INICC Report 2004-2009 -14

hospital over-crowding, lack of medical supplies, and in an insufficient number of experienced nurses or trained healthcare workers.

World Bank categorizes countries into four economic strata based on 2007 gross national income (GNI) per capita: (1)low income, $\$ 935$ or less; (2)lower middle income, $\$ 936-3,705$; (3)upper middle income, $\$ 3,706$ 11,455; and (4) high income, $\$ 11,456$ or more. ${ }^{31}$ Within this categorization, 144 out of 209 (68\%) are low-income and lower middle-income economies-which can also be referred to as lower income countries, low resources countries, developing economies, or developing or emerging countries-representing more than $75 \%$ of the world population. The relation between DA-HAl rates and the country socio economic level (low income, mid low income and high income), and between DA-HAl rates and their association to the type of hospital (Public, Academic, and Private) has recently analyzed, and published by INICC. 32

DA-HAI surveillance is primary and essential to reduce the hospitalized patients' risk of infection, because it effectively describes and addresses the importance and characteristics of the threatening situation created by HAls. This must be followed by the implementation of practices aimed at DA-HAl prevention and control. Additionally, participation in INICC has played a fundamental role, not only in increasing the awareness of DA$\mathrm{HAl}$ risks in the INICC ICUs, but also in providing an exemplary basis for the institution of infection control practices. In many INICC ICUs, for example, the high incidence of DA-HAI has been reduced by carrying out targeted performance feedback programs for hand hygiene and central line, mechanical ventilator, and urinary catheter care. ${ }^{33-39}$ Finally, it is of utmost importance to restrict the administration of anti-infective in order to effectively control of antibiotic resistance.

In order to compare a hospital's DA-HAl rates and DU ratios with the rates identified in this report, it is required that the hospital concerned starts collecting their data by applying the methods and methodology described for CDC NHSN and INICC, and then calculate infection rates and DU ratios for the Deviceassociated Module.

The major aim of these data is to serve as a guide for the implementation of prevention strategies and other quality improvement efforts locally, in order to help reduce DA-HAl rates to the minimum possible level.

In conclusion, the data presented in this report strengthen the fact that HAls, particularly DA-HAls in ICU patients in limited-resources countries, pose a grave and many times concealed risk to patient safety, as compared with the developed world. It is INICC's main goal to enhance infection control practices, by 
INICC Report 2004-2009 -15

facilitating elemental, feasible and inexpensive tools and resources to tackle this problem effectively and systematically, leading to greater and stricter adherence to infection control programs and guidelines, and to the correlated reduction in DA-HAI and its adverse effects, in the ICUs participating in INICC, as well as at any other healthcare facility of the developing world. 
INICC Report 2004-2009 -16

\section{REFERENCES}

1. Rosenthal VD, Guzman S, Orellano PW. Nosocomial infections in medical-surgical intensive care units in Argentina: attributable mortality and length of stay. Am J Infect Control 2003;31:291-5.

2. Rosenthal VD, Guzman S, Crnich C. Device-associated nosocomial infection rates in intensive care units of Argentina. Infect Control Hosp Epidemiol 2004;25:251-5.

3. Rosenthal VD, Maki DG, Salomao R, et al. Device-associated nosocomial infections in 55 intensive care units of 8 developing countries. Ann Intern Med 2006;145:582-91.

4. Ramirez Barba EJ, Rosenthal VD, Higuera F, et al. Device-associated nosocomial infection rates in intensive care units in four Mexican public hospitals. Am J Infect Control 2006;34:244-7.

5. Moreno CA, Rosenthal VD, Olarte N, et al. Device-associated infection rate and mortality in intensive care units of 9 Colombian hospitals: findings of the International Nosocomial Infection Control Consortium. Infect Control Hosp Epidemiol 2006;27:349-56.

6. Leblebicioglu H, Rosenthal VD, Arikan OA, et al. Device-associated hospital-acquired infection rates in Turkish intensive care units. Findings of the International Nosocomial Infection Control Consortium (INICC). J Hosp Infect 2007;65:251-7.

7. Mehta A, Rosenthal VD, Mehta Y, et al. Device-associated nosocomial infection rates in intensive care units of seven Indian cities. Findings of the International Nosocomial Infection Control Consortium (INICC). J Hosp Infect 2007;67:168-74.

8. Salomao R, Rosenthal VD, Grimberg G, et al. Device-associated infection rates in intensive care units of Brazilian hospitals: findings of the International Nosocomial Infection Control Consortium. Rev Panam Salud Publica 2008;24:195-202.

9. Cuellar LE, Fernandez-Maldonado E, Rosenthal VD, et al. Device-associated infection rates and mortality in intensive care units of Peruvian hospitals: findings of the International Nosocomial Infection Control Consortium. Rev Panam Salud Publica 2008;24:16-24.

10. Rosenthal VD, Maki DG, Mehta A, et al. International Nosocomial Infection Control Consortium report, data summary for 2002-2007, issued January 2008. Am J Infect Control 2008;36:627-37.

11. Pawar M, Mehta Y, Purohit A, Trehan N, Rosenthal VD. Resistance in gram-negative bacilli in a cardiac intensive care unit in India: risk factors and outcome. Ann Card Anaesth 2008;11:20-6.

12. Madani N, Rosenthal VD, Dendane T, Abidi K, Zeggwagh AA, Abouqal R. Health-care associated infections rates, length of stay, and bacterial resistance in an intensive care unit of Morocco: Findings of the International Nosocomial Infection Control Consortium (INICC). Int Arch Med 2009;2:29.

13. Rosenthal VD, Maki DG, Jamulitrat S, et al. International Nosocomial Infection Control Consortium (INICC) report, data summary for 2003-2008, issued June 2009. Am J Infect Control 2010;38:95-104 e2.

14. Navoa-Ng JA, Berba R, Arreza-Galapia Y, ., et al. Device-Associated Infections Rates in Adult, Pediatric and Neonatal Intensive Care Units of Hospitals from Philippines: International Nosocomial Infection Control Consortium (INICC) Findings. American Journal Infection Control 2011;In Press.

15. Guanche-Garcell H, Requejo-Pino O, Rosenthal VD, Morales-Pérez C, Delgado-González O, FernándezGonzález D. Device-Associated Infections Rates in Adults Intensive Care Units of University Cuban Hospitals: International Nosocomial Infection Control Consortium (INICC) Findings. Int J Infect Dis 2011; In Press.

16. Kanj SS, Nada Z, Rosenthal VD, Nisreen S, Lamia A, Zeina K. Device-Associated Infections Rate in an Intensive Care Unit of a Lebanese University Hospital: International Nosocomial Infection Control Consortium (INICC) Findings. Journal of Global Infectious Diseases 2011; In Press.

17. Dueñas L, Bran-de-Casares A, Rosenthal V.D., Jesús ML. Device-Associated Infections Rates in ICUs from El Salvador: INICC Findings. The Journal of Infection in Developing Countries 2011; In Press.

18. Edwards JR, Peterson KD, Andrus ML, Dudeck MA, Pollock DA, Horan TC. National Healthcare Safety Network (NHSN) Report, data summary for 2006 through 2007, issued November 2008. Am J Infect Control 2008;36:609-26.

19. Horan TC, Andrus M, Dudeck MA. CDC/NHSN surveillance definition of health care-associated infection and criteria for specific types of infections in the acute care setting. Am J Infect Control 2008;36:309-32.

20. Emori TG, Culver DH, Horan TC, et al. National nosocomial infections surveillance system (NNIS): description of surveillance methods. Am J Infect Control 1991;19:19-35. 
21. Rosenthal VD, Udwadia FE, Munoz HJ, et al. Time-dependent analysis of extra length of stay and mortality due to ventilator-associated pneumonia in intensive-care units of ten limited-resources countries: findings of the International Nosocomial Infection Control Consortium (INICC). Epidemiol Infect 2011:1-7.

22. Barnett AG, Graves N, Rosenthal VD, Salomao R, Rangel-Frausto MS. Excess length of stay due to central lineassociated bloodstream infection in intensive care units in Argentina, Brazil, and Mexico. Infect Control Hosp Epidemiol 2010;31:1106-14.

23. Rosenthal VD, Dwivedy A, Calderon ME, et al. Time-dependent analysis of length of stay and mortality due to urinary tract infections in ten developing countries: INICC findings. J Infect 2010;62:136-41.

24. Barnett AG, Beyersmann J, Allignol A, Rosenthal VD, Graves N, Wolkewitz M. The Time-Dependent Bias and its Effect on Extra Length of Stay due to Nosocomial Infection. Value Health 2011;14:381-6.

25. Rosenthal VD, Maki DG, Graves N. The International Nosocomial Infection Control Consortium (INICC): Goals and objectives, description of surveillance methods, and operational activities. Am J Infect Control 2008;36:e1-e12.

26. Garner JS, Jarvis WR, Emori TG, Horan TC, Hughes JM. CDC definitions for nosocomial infections, 1988. Am J Infect Control 1988;16:128-40.

27. Hidron AI, Edwards JR, Patel J, et al. NHSN annual update: antimicrobial-resistant pathogens associated with healthcare-associated infections: annual summary of data reported to the National Healthcare Safety Network at the Centers for Disease Control and Prevention, 2006-2007. Infect Control Hosp Epidemiol 2008;29:996-1011.

28. Hughes JM. Study on the efficacy of nosocomial infection control (SENIC Project): results and implications for the future. Chemotherapy 1988;34:553-61.

29. Rosenthal VD. Health-care-associated infections in developing countries. Lancet 2011;377:186-8.

30. Allegranzi B, Bagheri Nejad S, Combescure C, et al. Burden of endemic health-care-associated infection in developing countries: systematic review and meta-analysis. Lancet;377:228-41.

31. The World Bank. The World Bank List of Economies The World Bank, 2008. (Accessed May 12, 2010, 2010, at http://www.worldbank.org/.)

32. Rosenthal VD, Lynch P, Jarvis RW, et al. Socioeconomic Impact on Device-Associated Infections in LimitedResource Neonatal Intensive Care Units: Findings of INICC. Infection 2011; In Press.

33. Rosenthal VD, McCormick RD, Guzman S, Villamayor C, Orellano PW. Effect of education and performance feedback on handwashing: the benefit of administrative support in Argentinean hospitals. Am J Infect Control 2003;31:85-92.

34. Rosenthal VD, Guzman S, Pezzotto SM, Crnich CJ. Effect of an infection control program using education and performance feedback on rates of intravascular device-associated bloodstream infections in intensive care units in Argentina. Am J Infect Control 2003;31:405-9.

35. Rosenthal VD, Guzman S, Safdar N. Effect of education and performance feedback on rates of catheter-associated urinary tract infection in intensive care units in Argentina. Infect Control Hosp Epidemiol 2004;25:47-50.

36. Higuera F, Rosenthal VD, Duarte P, Ruiz J, Franco G, Safdar N. The effect of process control on the incidence of central venous catheter-associated bloodstream infections and mortality in intensive care units in Mexico. Crit Care Med 2005;33:2022-7.

37. Rosenthal VD, Guzman S, Safdar N. Reduction in nosocomial infection with improved hand hygiene in intensive care units of a tertiary care hospital in Argentina. Am J Infect Control 2005;33:392-7.

38. Rosenthal VD, Guzman S, Crnich C. Impact of an infection control program on rates of ventilator-associated pneumonia in intensive care units in 2 Argentinean hospitals. Am J Infect Control 2006;34:58-63.

39. Rosenthal VD, Maki DG, Rodrigues C, et al. Impact of International Nosocomial Infection Control Consortium (INICC) strategy on central line-associated bloodstream infection rates in the intensive care units of 15 developing countries. Infect Control Hosp Epidemiol 2010;31:1264-72. 


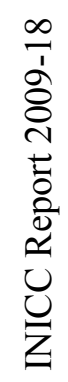

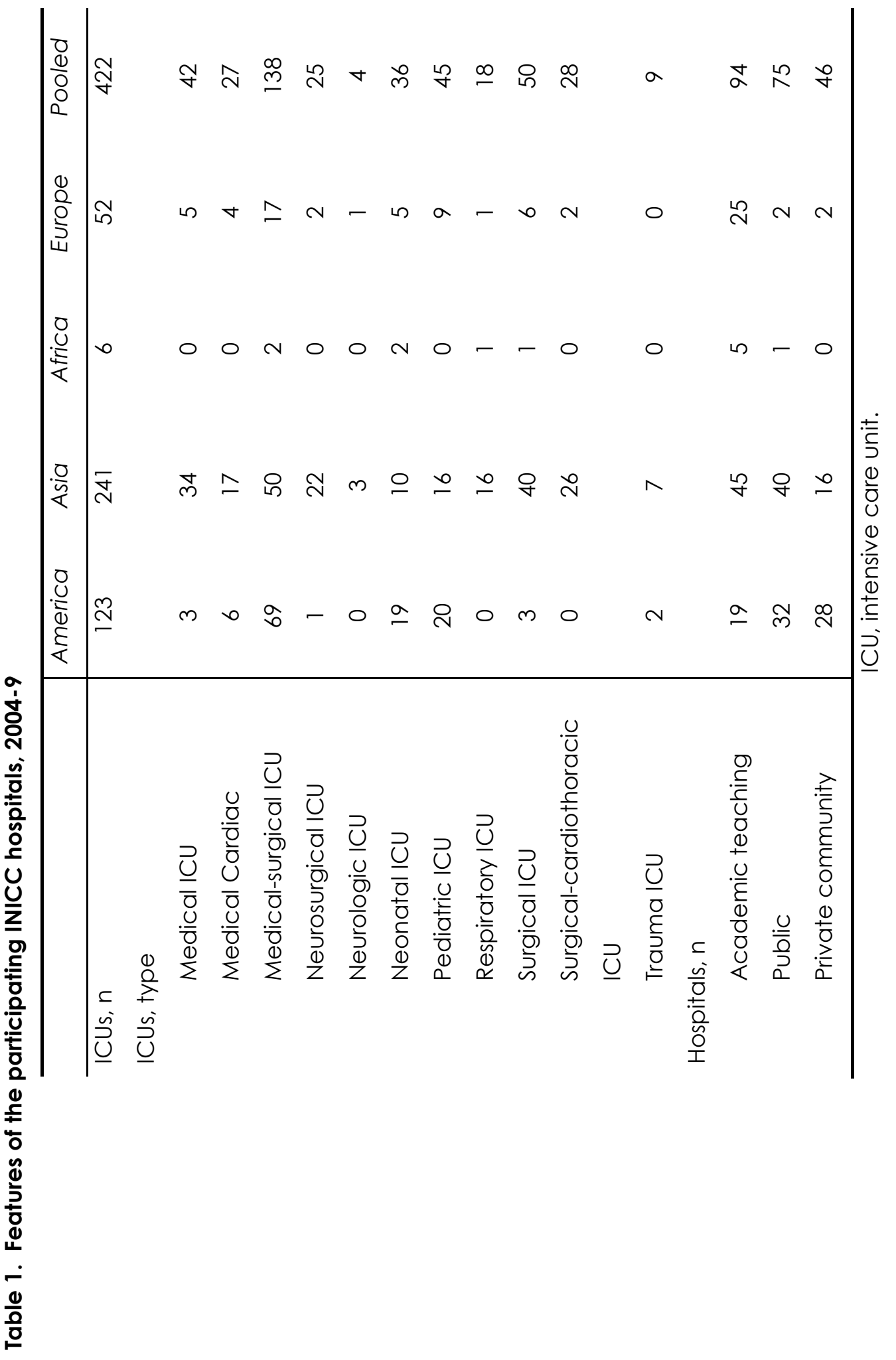




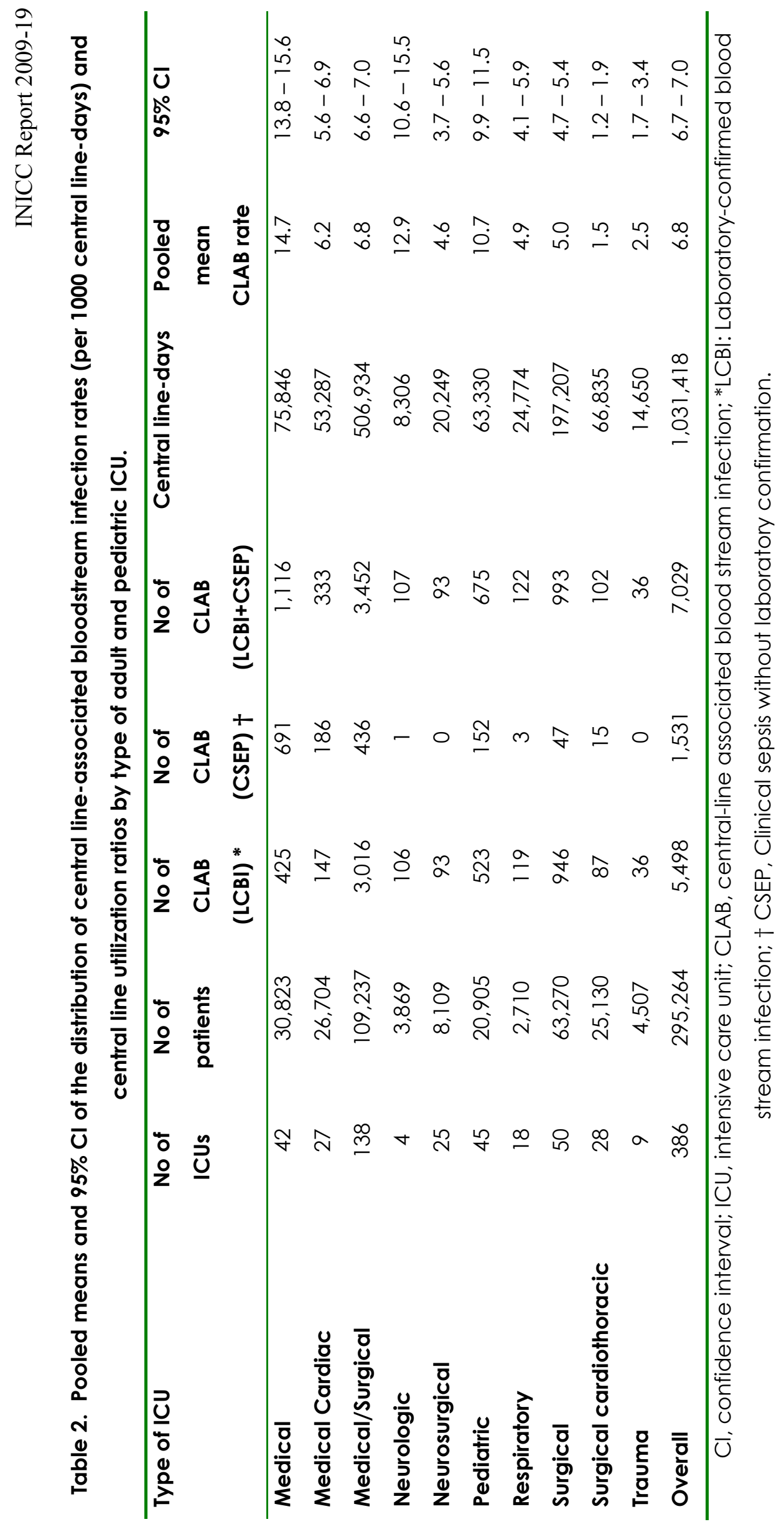




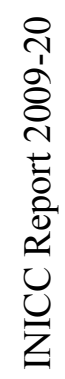

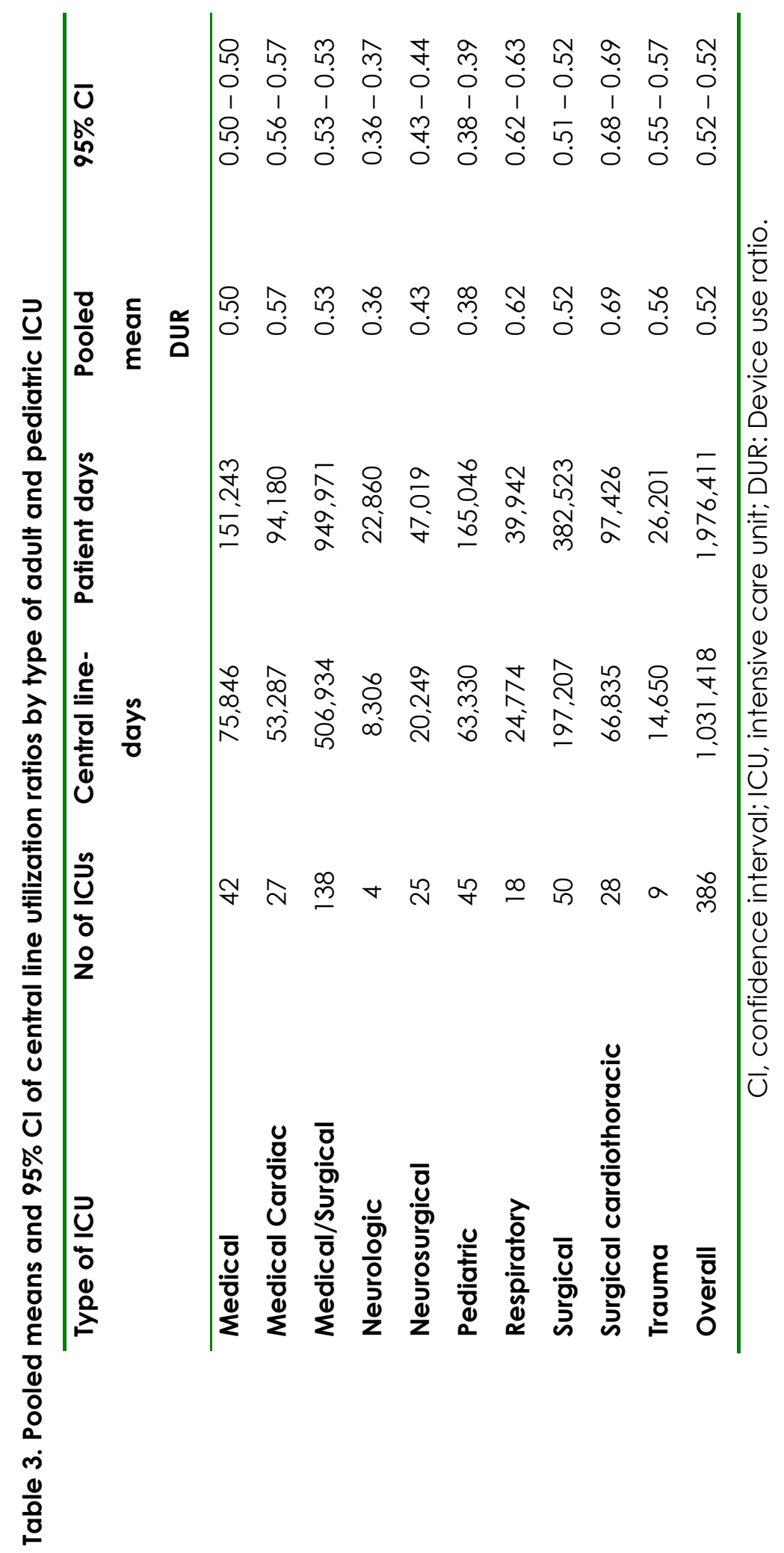




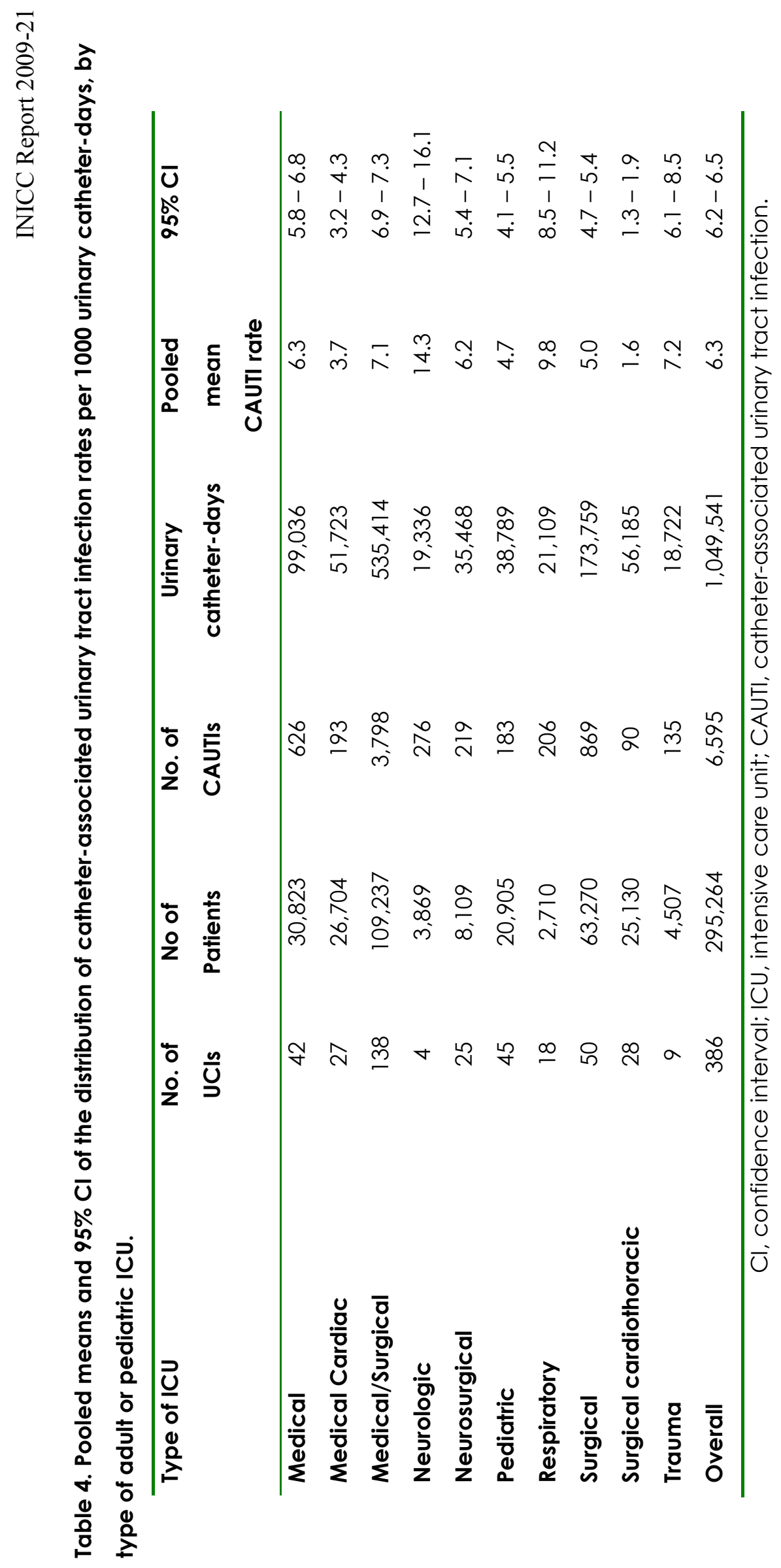




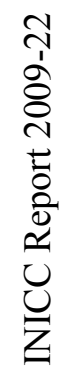

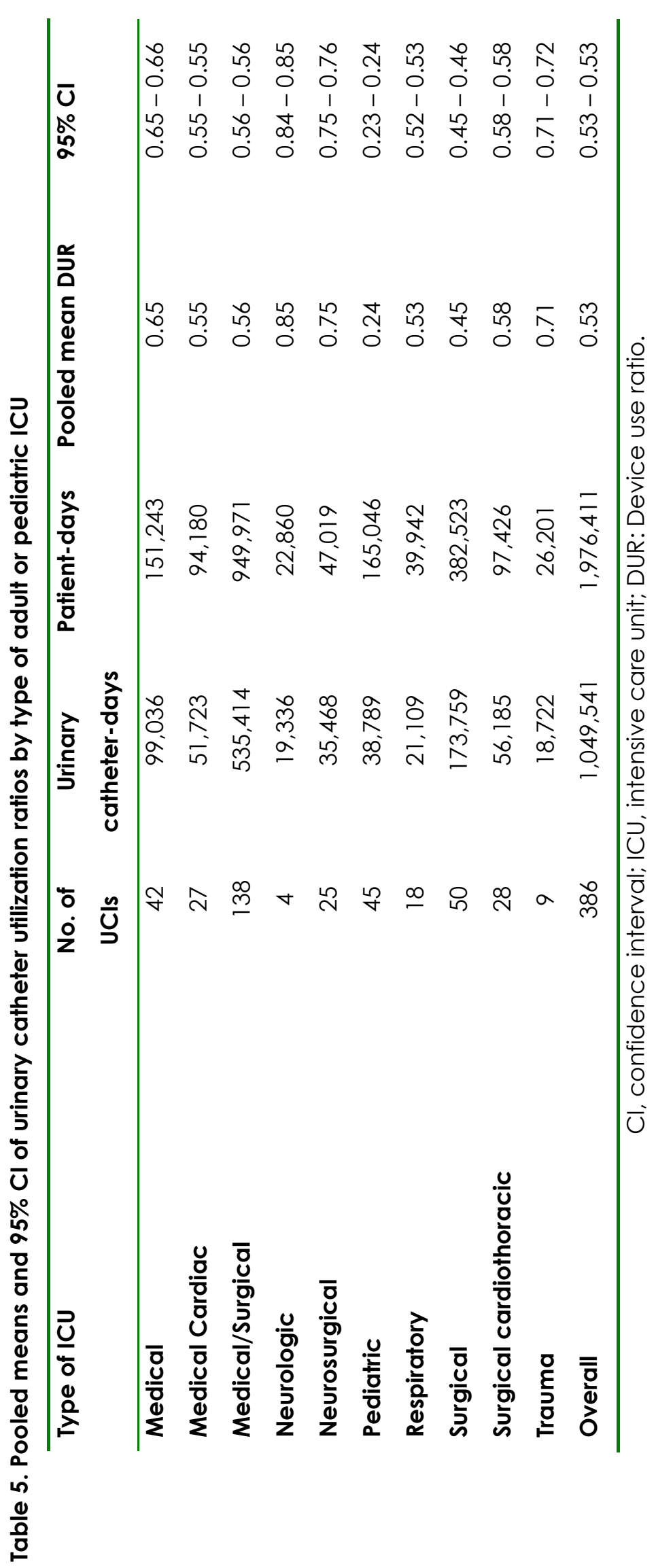




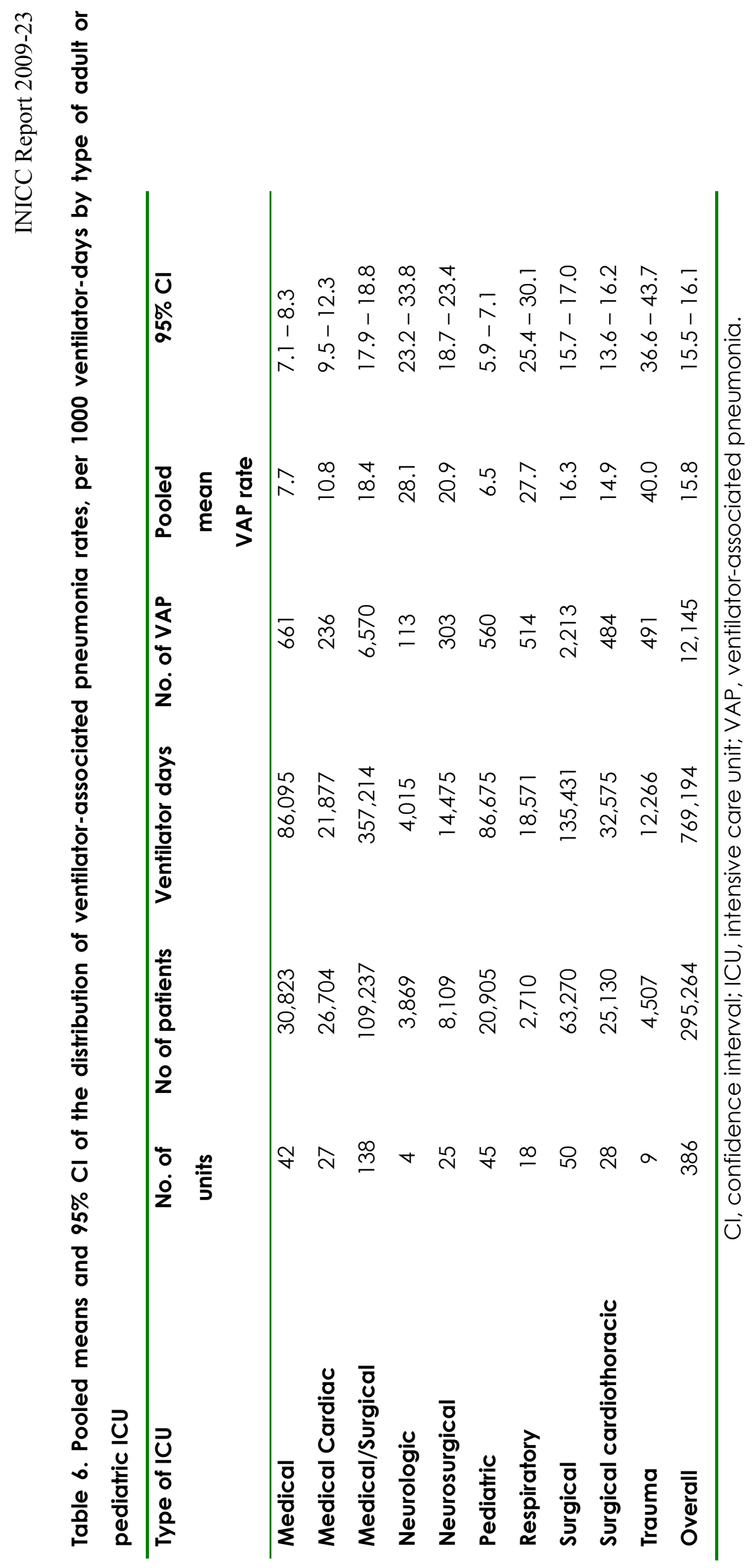




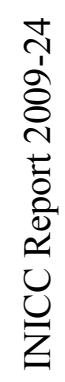

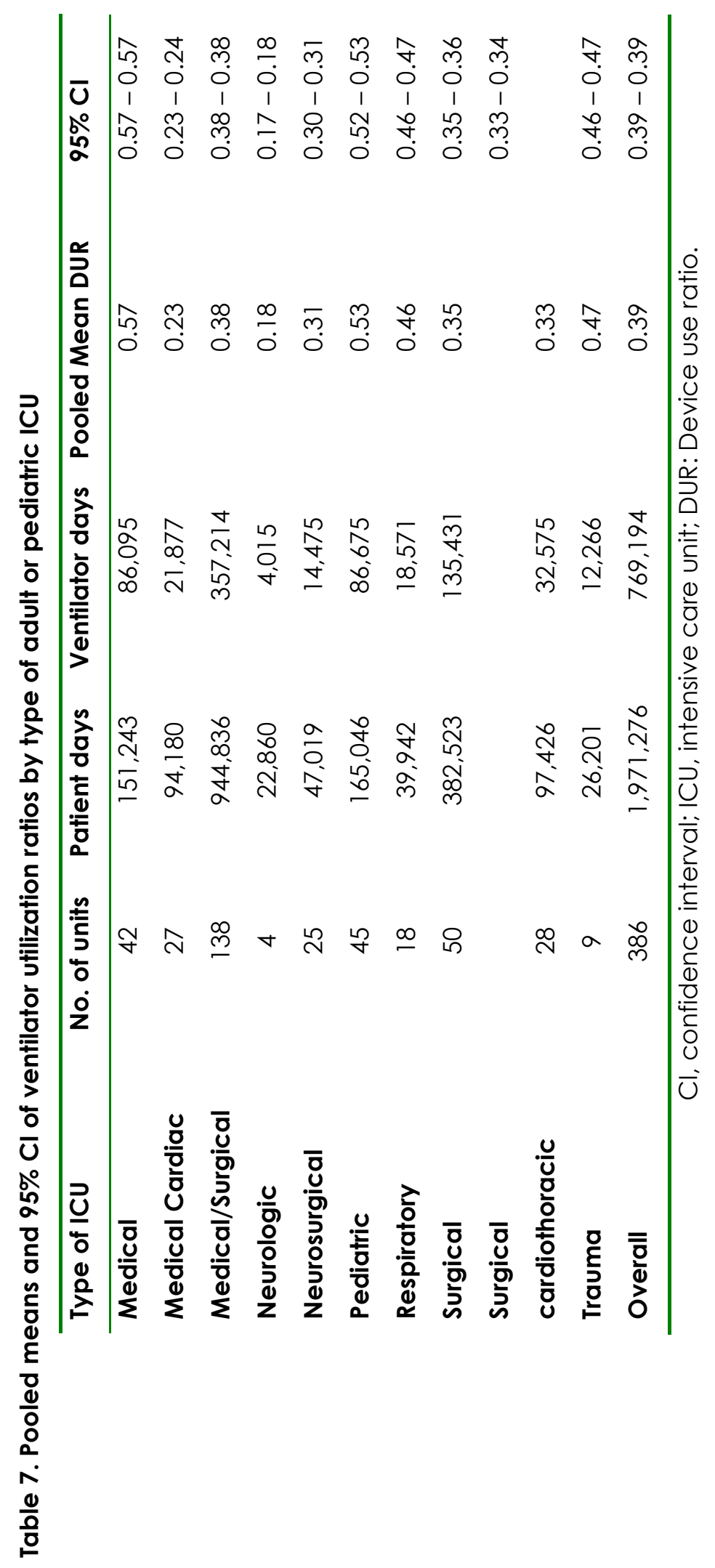




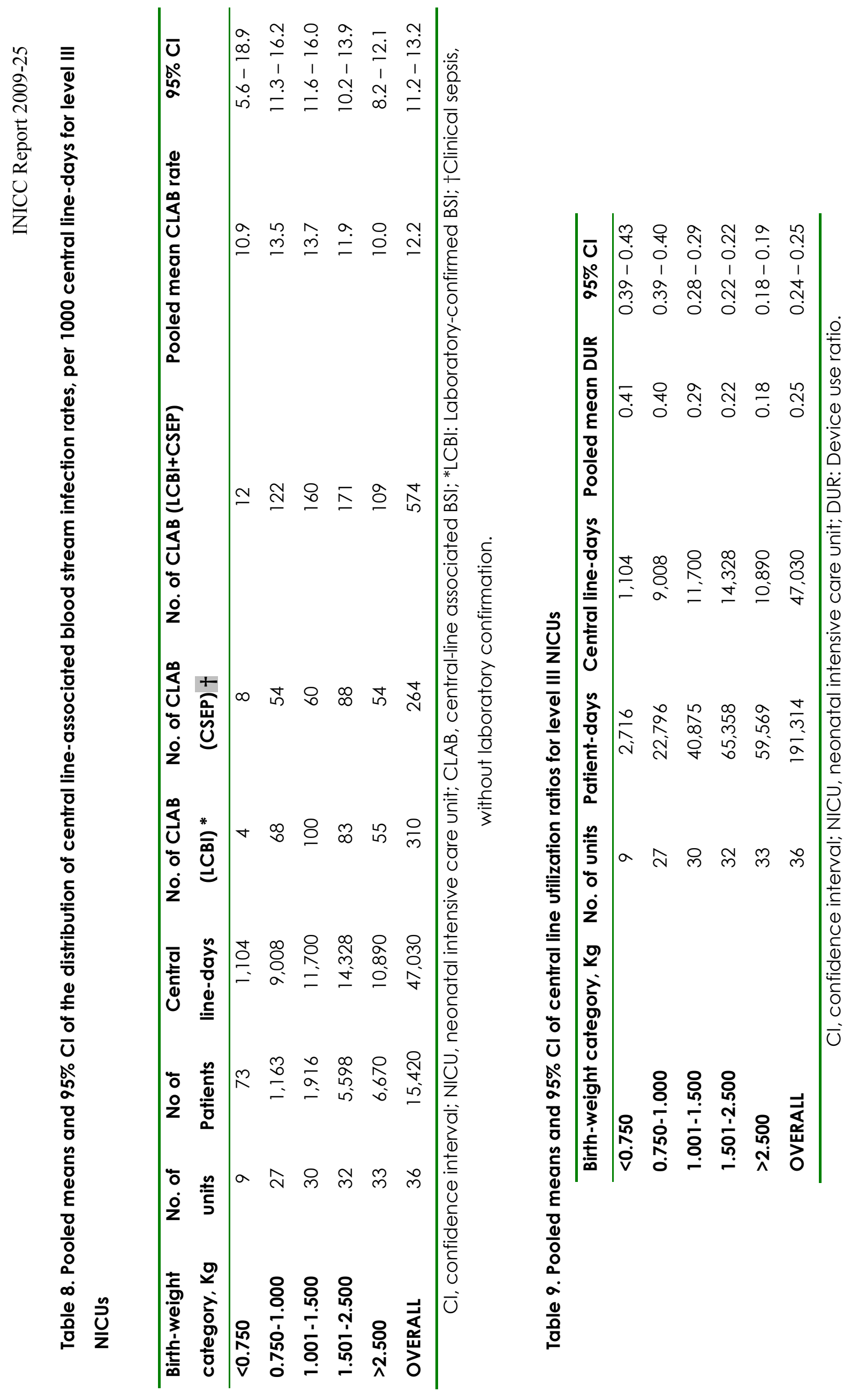




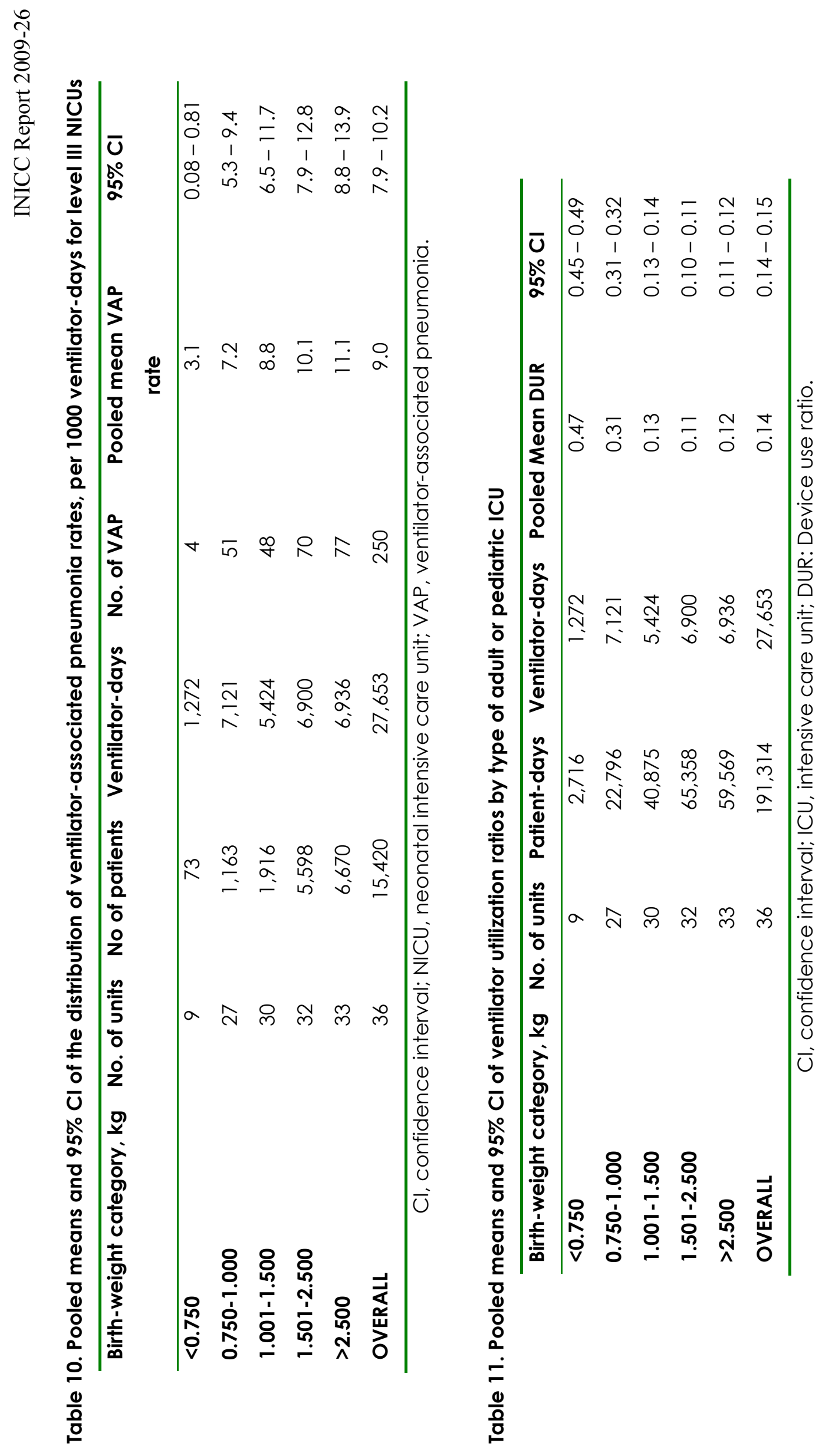




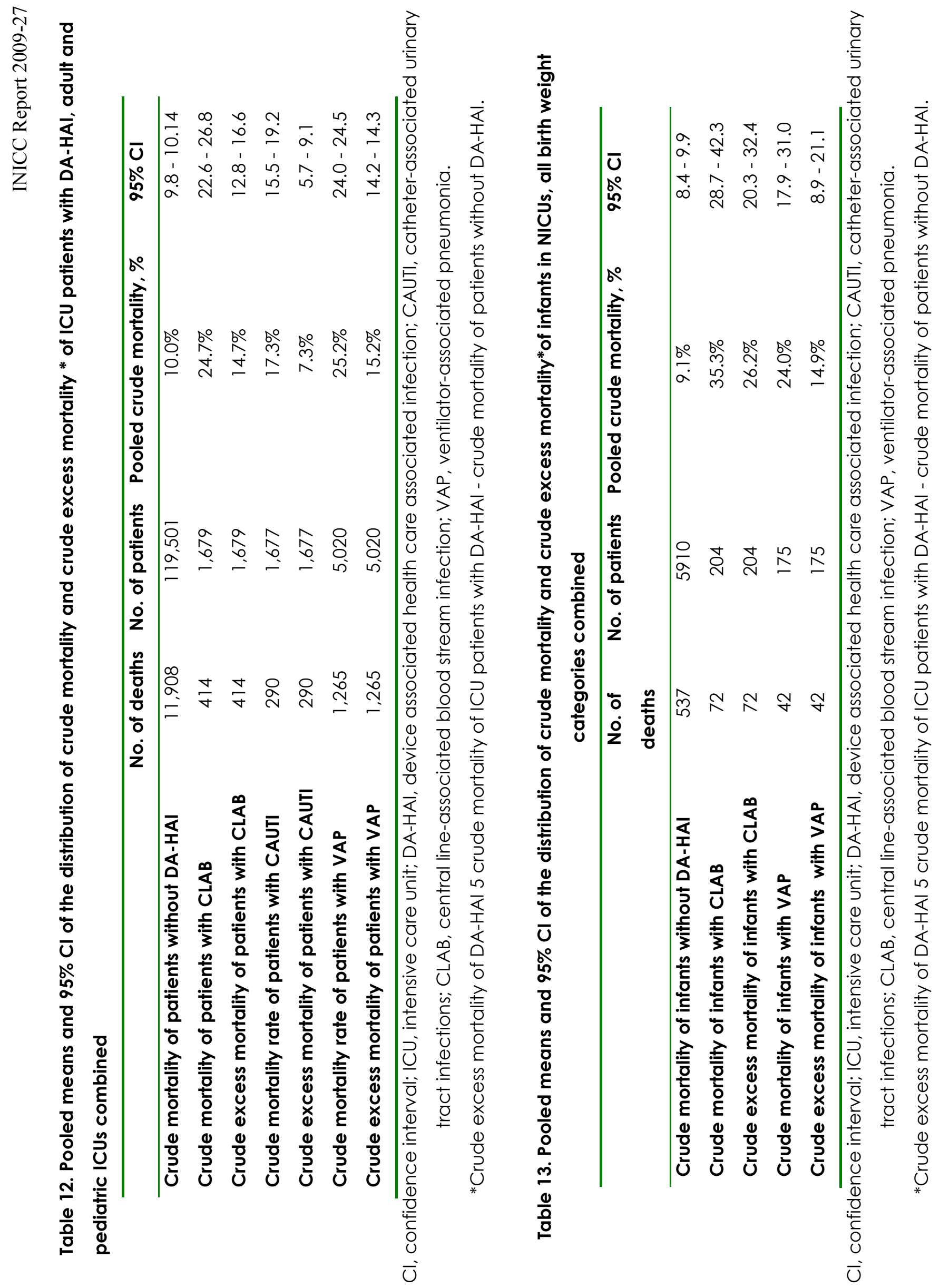




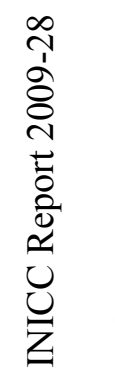

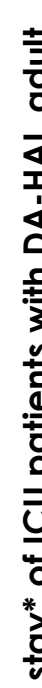

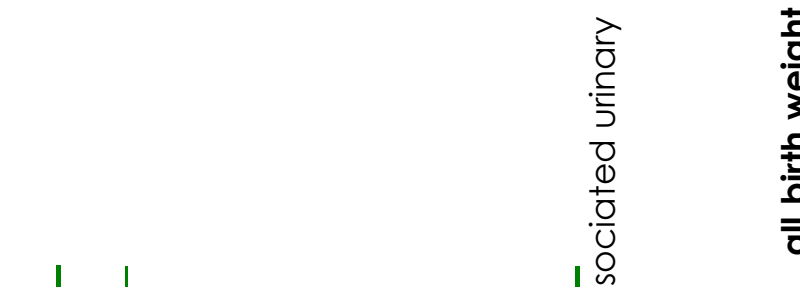

\begin{tabular}{l}
$\frac{ \pm}{0}$ \\
$\frac{0}{3}$ \\
$\frac{5}{0}$ \\
$\overline{\frac{t}{0}}$ \\
\hline
\end{tabular}

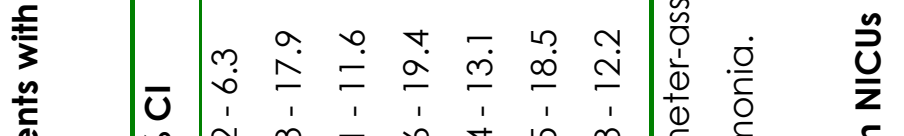

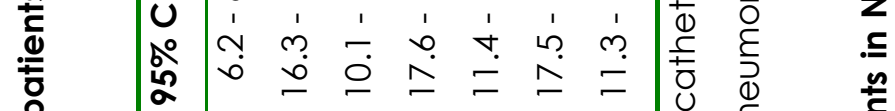

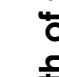

fo

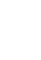

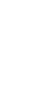

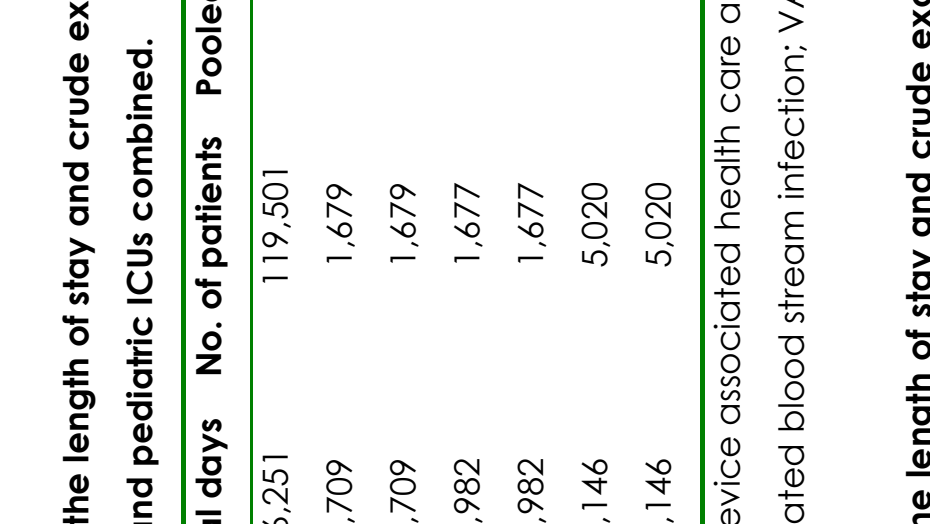

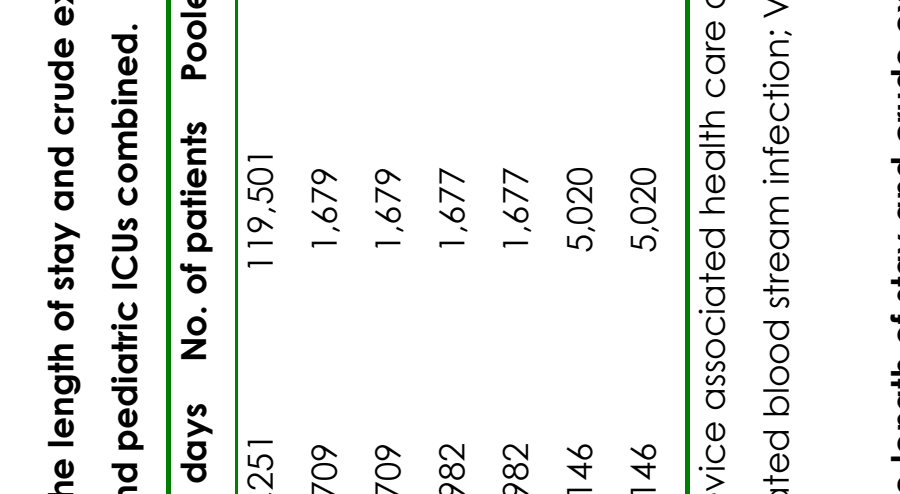

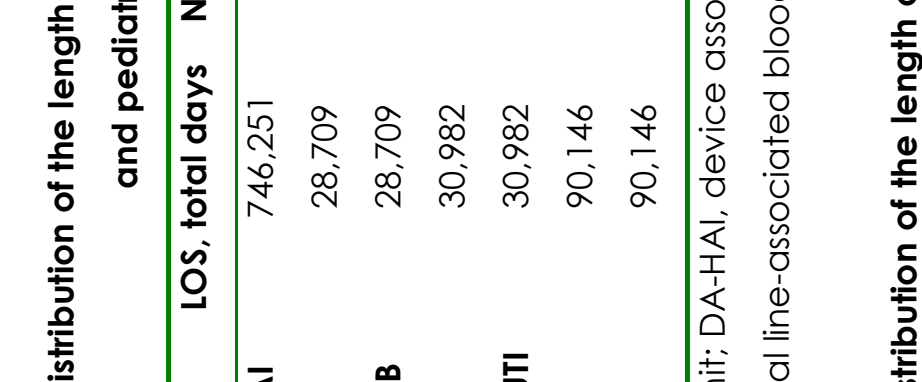

产

旁

ธั

s

(a)

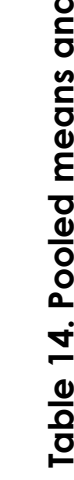




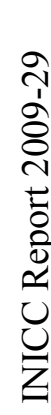

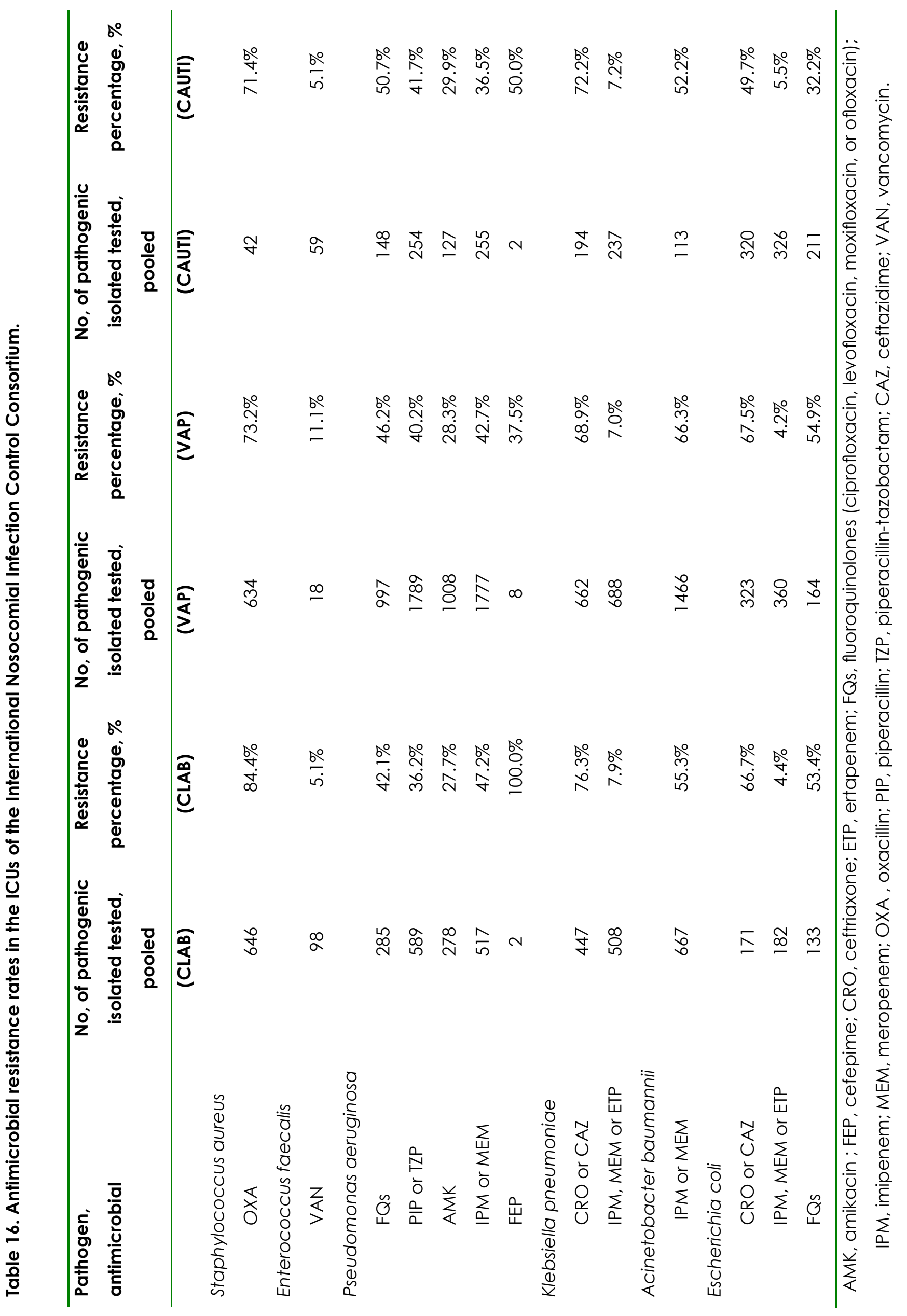




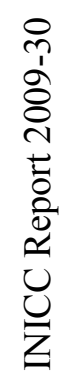

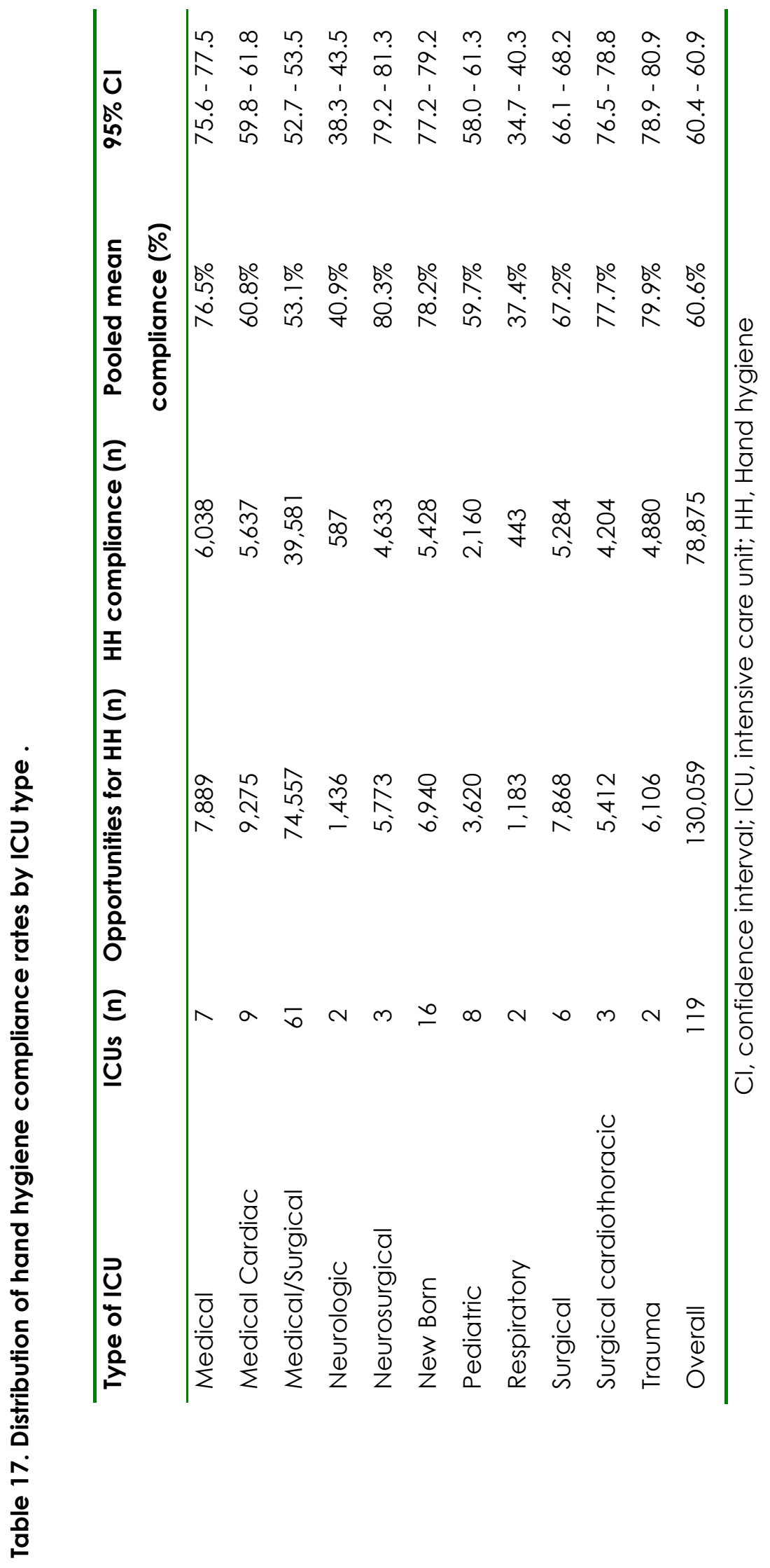



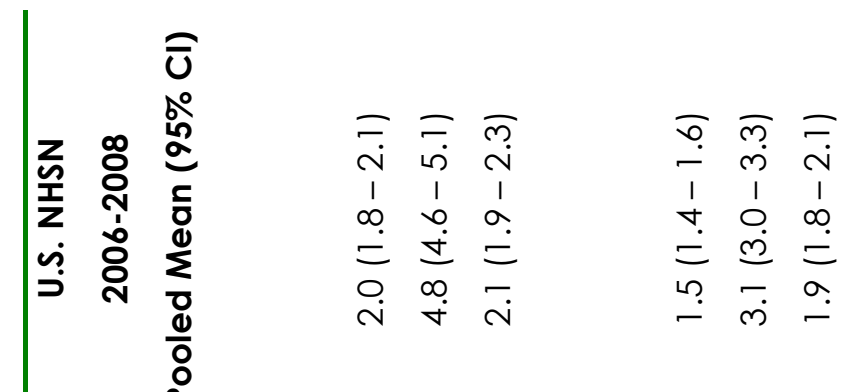

\section{$\overline{\bar{g}}$}

ชั

z

ธุ

政

政

$\frac{1}{5}$

$$
\text { 을 }
$$

$$
\stackrel{5}{5}
$$$$
\text { 列 }
$$$$
\text { ำ }
$$

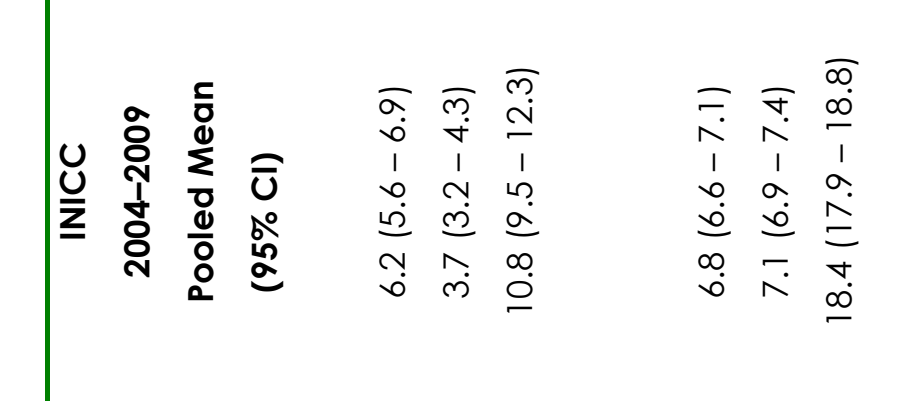

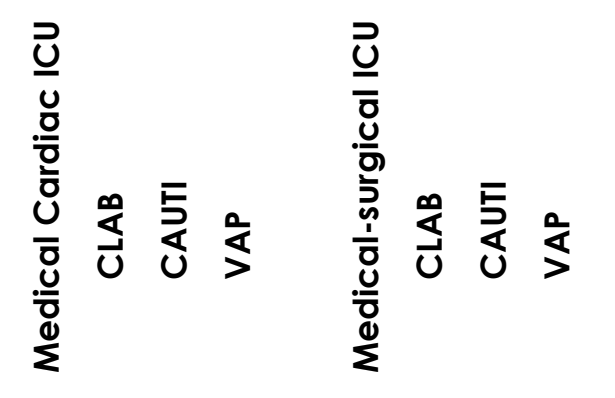

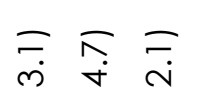

$\begin{array}{lll}1 & 1\end{array}$

ก. $\infty$.

$\therefore \stackrel{m}{=}$

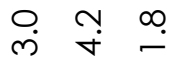
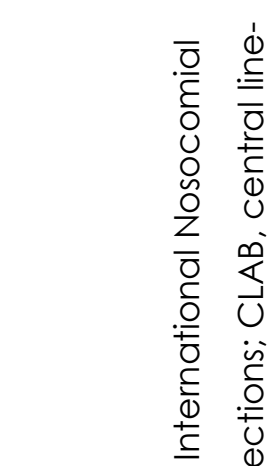

U $\stackrel{4}{.}$

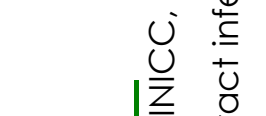

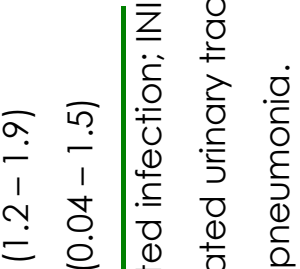

ᄂ?

$\begin{array}{ll}\frac{0}{0} & \frac{0}{U} \\ \frac{0}{U} & 0 \\ O & 0 \\ \tilde{n} & 0 \\ 0 & 0 \\ 0 & 1\end{array}$

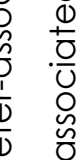

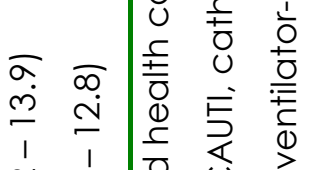

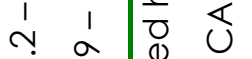

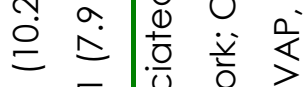

$\stackrel{\circ}{=}$

竞

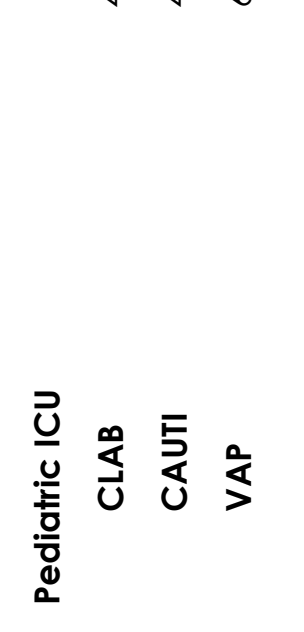




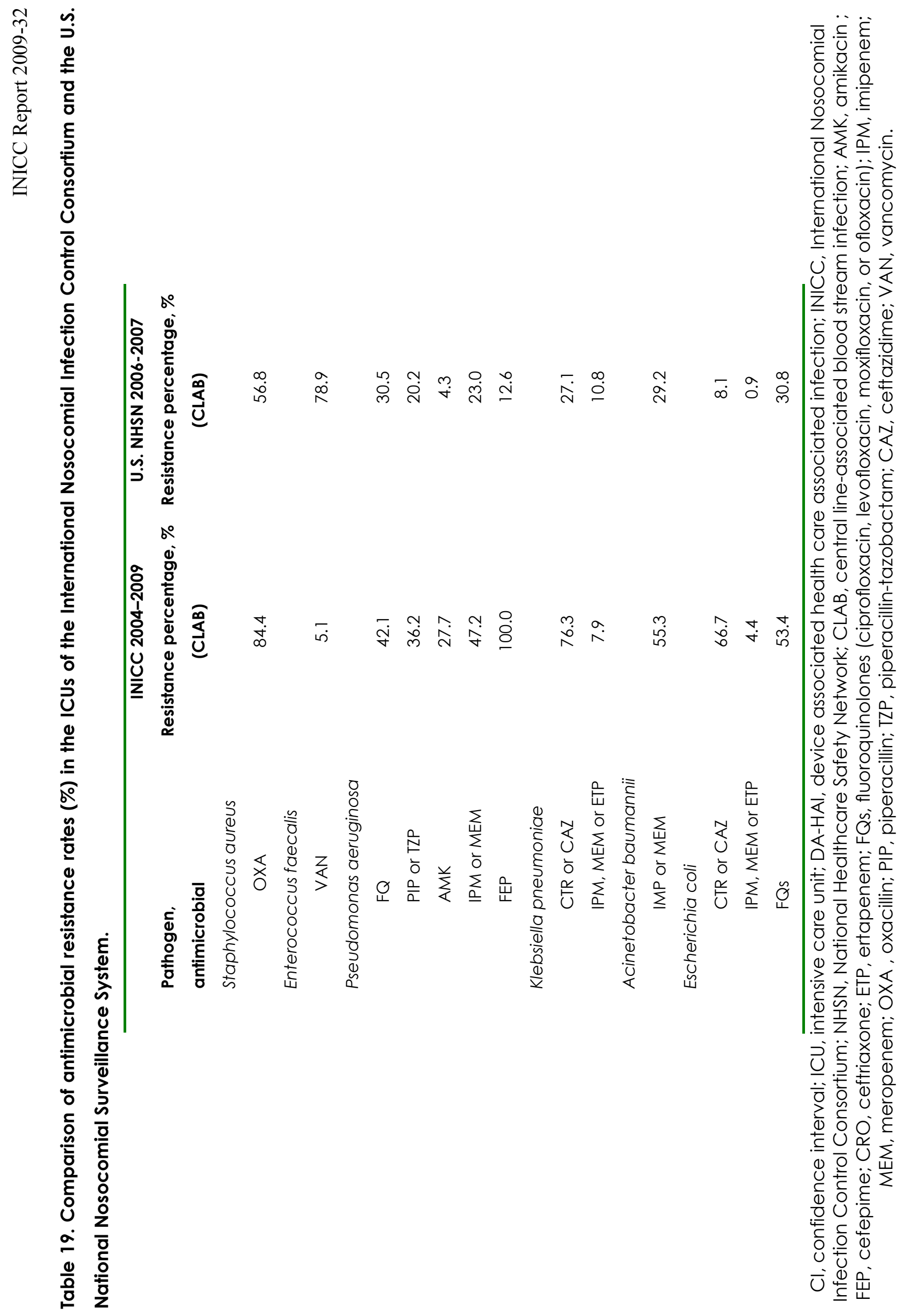


ह

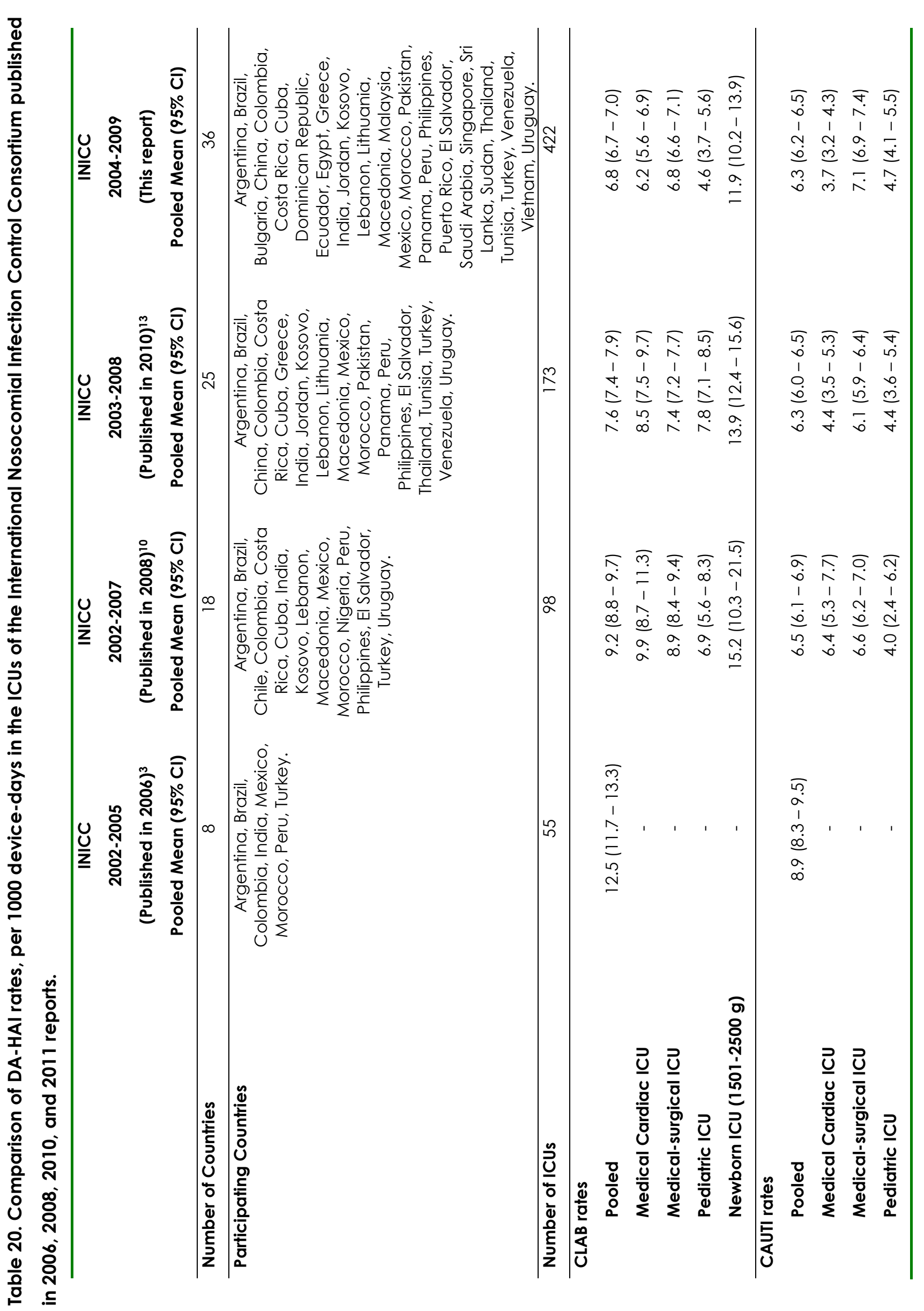




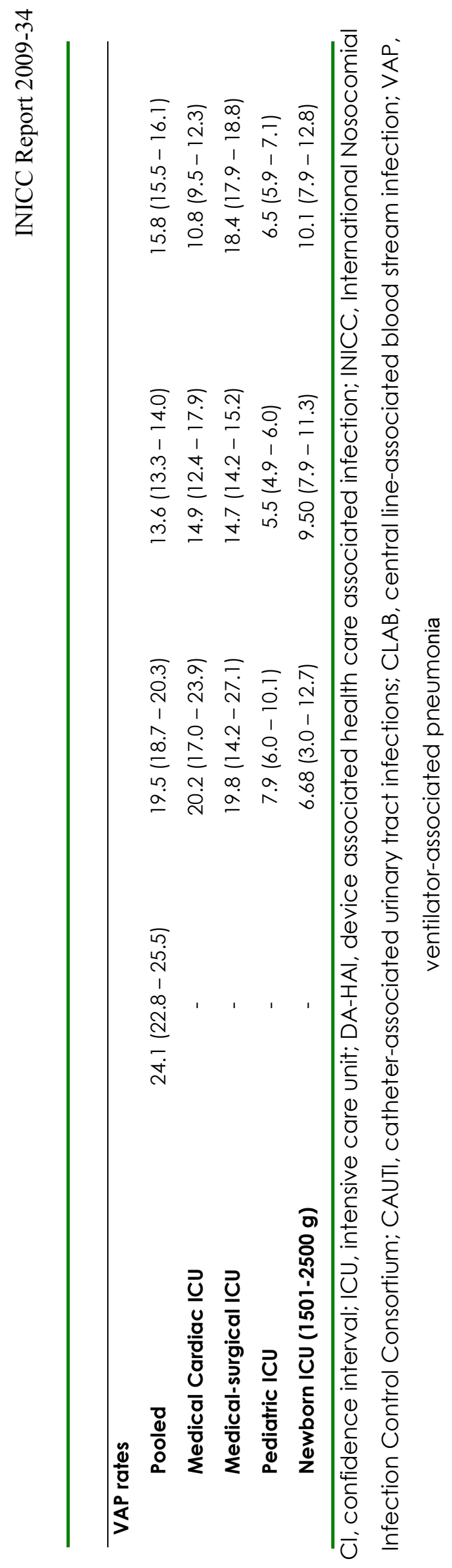

